\title{
Vochysiaceae na região do Planalto de Diamantina, Minas Gerais, Brasil
}

\author{
Vochysiaceae from the Diamantina Plateau region, Minas Gerais, Brazil
}

Deise Josely Pereira Gonçalves ${ }^{1,2,4}$, Gustavo Hiroaki Shimizu ${ }^{1}$, Kikyo Yamamoto ${ }^{3}$ \& João Semir ${ }^{3}$

\begin{abstract}
Resumo
Vochysiaceae está representada no Brasil por ca. 160 espécies distribuídas principalmente na Floresta Amazônica, na Floresta Atlântica e no Cerrado. O Planalto de Diamantina localiza-se ao norte da Serra do Cipó e ao sul de Grão Mogol, na porção centro-sul da Cadeia do Espinhaço. Na área de estudo foram inventariadas 22 espécies pertencentes à família Vochysiaceae, distribuídas nos gêneros Vochysia (13 spp.), Qualea (5 spp.), Callisthene (3 spp.) e Salvertia (1 sp.). São apresentadas chaves para identificação e descrições morfológicas de gêneros e espécies, além de informações sobre a distribuição geográfica, comentários taxonômicos, ecológicos e ilustrações de caracteres diagnósticos.
\end{abstract}

Palavras-chave: Cadeia do Espinhaço, campos rupestres, Cerrado, florística, taxonomia.

\begin{abstract}
Vochysiaceae is represented in Brazil by ca. 160 species, distributed mainly the in Amazon Forest, Atlantic Forest, and Cerrado. The Diamantina Plateau is located between the north of Serra do Cipó and the south of Grão Mogol, in the Espinhaço Range central southern region. We have found 22 species of Vochysiaceae in the studied area, distributed among the genera Vochysia (13 spp.), Qualea (5 spp.), Callisthene (3 spp.), and Salvertia (1 sp.). We present identification keys and morphological descriptions of genera and species, as well as information about the geographical distribution, taxonomic and ecological remarks, and illustrations of diagnostic features.
\end{abstract}

Key words: Espinhaço Range, campos rupestres, Cerrado, floristics, taxonomy.

\section{Introdução}

Vochysiaceae A.St.-Hil. compreende cerca de 240 espécies distribuídas do sul da América do Norte ao centro-sul da América do Sul, e em uma região no oeste do continente africano (Senterre \& Obiang 2005; Shimizu \& Yamamoto 2012b). A família compreende oito gêneros, dos quais dois (Erismadelphus Mildbr. e Korupodendron Litt \& Cheek) ocorrem apenas na África e os demais (Callisthene Mart., Erisma Rudge, Qualea Aubl., Ruizterania Marc.-Berti, Salvertia A.St.-Hil. e Vochysia Aubl.) ocorrem exclusivamente no continente americano, principalmente no Brasil, onde há registro de cerca de 160 espécies da família (Souza \& Lorenzi 2012; BFG 2015). Os representantes da família possuem hábito arbóreo, arbustivo ou subarbustivo, folhas simples com filotaxia oposta ou verticilada, flores zigomorfas, cálice geralmente calcarado e apenas um estame fértil (Kawasaki 2006). A morfologia da flor, do fruto e da semente tradicionalmente divide a família nas tribos Vochysieae Dumort. e Erismeae Dumort. (Kawasaki 2006). Vochysiaceae, em especial a tribo Vochysieae, é importante na caracterização de fitofisionomias do domínio dos Cerrados, sendo considerada um componente típico destas formações vegetais (Sarmiento 1983). Estudos filogenéticos preliminares sugerem a existência dos clados Erismeae, Vochysia s.l. (Salvertia e Vochysia) e Qualea s.l. (Callisthene, Qualea e Ruizterania), apresentando Erismeae ora como grupo-irmão de Vochysia s.l., ora de Qualea s.l.

\footnotetext{
${ }^{1}$ Universidade Estadual de Campinas, Inst. Biologia, Depto. Biologia Vegetal, Prog. Pós-graduação em Biologia Vegetal, C.P. 6109, 13083-970, Campinas, SP, Brasil.

${ }^{2}$ The University of Texas at Austin, Department of Integrative Biology, $205 \mathrm{~W} 24^{\text {th }}$ Street, Stop C0930, 78712, Austin, TX, U.S.A.

${ }^{3}$ Universidade Estadual de Campinas, Inst. Biologia, Depto. Biologia Vegetal, C.P. 6109, 13083-970, Campinas, SP, Brasil.

${ }^{4}$ Autor para correspondência: deisejpg@gmail.com / deisejpg@utexas.edu
} 
(Litt 1999). Apesar dessa indicação, como ainda não foi realizada uma revisão formal propondo um novo rearranjo dentro da família, a atual divisão entre as duas tribos e os seus gêneros tem sido adotada em estudos taxonômicos (p. ex. Yamamoto 2009; Shimizu \& Yamamoto 2012a; Gonçalves et al. 2013).

O Planalto de Diamantina (PD), localizado na porção centro-sul da Cadeia do Espinhaço (CE), está situado ao norte da Serra do Cipó e ao sul de Grão Mogol. A região constitui o teto orográfico regional, sendo o centro irradiador de drenagem dos rios São Francisco na face oeste e, na face leste, dos Rios Jequitinhonha, Araçuaí e dos afluentes da margem direita do Rio Doce (Saadi 1995). O Planalto de Diamantina foi considerado um dos centros de maior diversidade e endemismo de plantas na Cadeia do Espinhaço (Giulietti et al. 1997; Echternacht et al. 2011). Semir (1991) e Rapini et al. (2002) concluíram que o PD, juntamente com a Serra do Cipó, constituem as áreas de maior taxa de endemismo e de maior riqueza em número de espécies para Lychnophora (Asteraceae) e Asclepiadoideae (Apocynaceae), respectivamente.

A família Vochysiaceae foi objeto de estudo em regiões ao longo da Cadeia do Espinhaço. Passos \& França (2003), Yamamoto (2009) e Shimizu \& Yamamoto (2012a) realizaram o estudo taxonômico da família na Chapada Diamantina, em Grão Mogol e na Serra do Cipó, respectivamente. O presente trabalho apresenta os resultados do estudo taxonômico das espécies de Vochysiaceae ocorrentes na região do Planalto de Diamantina, Minas Gerais. O tratamento taxonômico é composto por chaves de identificação para gêneros e espécies, descrições morfológicas, comentários sobre características diagnósticas, comentários taxonômicos e ecológicos, dados sobre distribuição geográfica, hábitat, períodos de floração e frutificação e ilustrações dos táxons.

\section{Material e Métodos}

O Planalto de Diamantina localiza-se na porção centro-sul da Cadeia do Espinhaço, que se estende do estado da Bahia a Minas Gerais, entre as latitudes $10^{\circ} \mathrm{S}$ e $20^{\circ} 35^{\prime} \mathrm{S}$ e as longitudes $40^{\circ} 10^{\prime} \mathrm{O}$ e $44^{\circ} 30^{\prime} \mathrm{O}$, em uma faixa de cerca de $1200 \mathrm{~km}$ em direção N-S com larguras de 50 a 100 km (Giulietti et al. 1997; Abreu et al. 2005). O clima na porção mineira da CE é do tipo mesotérmico Cwb (Köppen 1931). A temperatura média anual situa-se na faixa de $18^{\circ}$ a $19^{\circ} \mathrm{C}$ e a precipitação média anual varia de 1250 a $1550 \mathrm{~mm}$ (Neves et al. 2005). Os solos da região são normalmente rasos, arenosos, ácidos, extremamente pobres em nutrientes e rochas quartzíticas e areníticas afloram por toda a parte (Joly 1970; Giulietti et al. 1997; Abreu et al. 2005).

A fim de realizar comparações florísticas entre diferentes localidades da porção mineira da CE, Rapini et al. (2002) dividiram a região em quatro faixas latidudinais: Sul (de Ouro Preto a Caeté); Serra do Cipó (de Santa Luzia a Congonhas do Norte); Planalto de Diamantina (de Presidente Kubitschek a Itamarandiba, incluindo a Serra do Cabral); e Norte (de Itacambira a Espinosa). Neste trabalho adotamos a delimitação de Rapini et al. (2002) para o Planalto de Diamantina, mas excluindo a Serra do Cabral, pois esta é uma serra disjunta do restante da $\mathrm{CE}$ devido à depressão drenada pelos rios Jequitaí e Curimataí (Saadi 1995). Foram considerados os seguintes limites para o PD: limites norte e leste no município de Itamarandiba (18 $17^{\circ} 38^{\prime \prime}$, 4403'13"O), limite sul no município de Presidente Kubitschek (18³6'53"S, 4333'43"O) e limite oeste no município de Monjolos (18 $19^{\circ} 31^{\prime \prime S}$, 4407'09'O). Além destes, o PD compreende Diamantina, Gouveia, Datas, Conselheiro Mata, Guinda, Santo Antônio do Itambé, São Gonçalo do Rio Preto e Senador Modestino Gonçalves.

Foram realizadas oito expedições a campo nos anos de 2010, 2011 e 2012, em diferentes épocas do ano, de modo a realizar coletas em todos os municípios que compõem o PD durante as estações seca e chuvosa. Uma expedição adicional foi realizada em 2014, em busca de novas amostras de provável espécie nova de Vochysia. Na área de estudo existem as seguintes reservas naturais: APA Pau de Frutas, Parque Estadual do Biribiri, Parque Estadual do Pico do Itambé, Parque Estadual do Rio Preto, Estação Ecológica Mata dos Ausentes e Parque Nacional das Sempre Vivas. Todas foram visitadas pelo menos uma vez e os representantes da família Vochysiaceae foram fotografados e coletados.

Os seguintes herbários foram consultados: BHCB, DIAM, ESA, F, GUA, HUFU, MBM, MO, NY, SP, SPF, TEX, UEC, UPCB, US e VIC (siglas segundo Thiers [continuamente atualizado]). O material coletado foi depositado no herbário UEC e duplicatas foram doadas ao herbário DIAM. As identificações das espécies são apoiadas na revisão de Stafleu $(1948,1952,1953)$ e nos trabalhos de Yamamoto (2009) e Shimizu \& Yamamoto (2012a). As descrições da família, dos gêneros e das 
espécies foram baseadas no material examinado, e também nos trabalhos de Warming (1875) e Stafleu $(1948,1952,1953)$. A terminologia morfológica segue Radford et al. (1974). O termo âmbito foi utilizado para caracterizar o contorno dos râmulos filomórficos de Callisthene. Os termos incurvo (curvado para cima, em direção à sépala) e recurvo (curvado para baixo, em direção ao pedicelo), referentes à curvatura do cálcar, seguem Stearn (2004). Para as medidas de elementos florais foram utilizadas flores abertas ou começando a abrir e as medidas dos frutos foram tomadas de frutos presentes no material examinado ou, quando necessário, foram utilizados dados da literatura. As medidas do comprimento dos botões florais foram tomadas da base do cálice ao ápice da sépala calcarada, excluindo-se o cálcar. Comentários sobre floração e frutificação foram baseados em informações contidas no material examinado. Comentários sobre a distribuição geográfica são baseados no material examinado, em Stafleu (1948, 1952, 1953) e demais trabalhos com a família. Quando necessário, material de outras áreas foi incluído como "material adicional examinado" para complementar ou melhorar a caracterização das espécies. As abreviações dos nomes dos autores seguem Brummitt \& Powell (1992).

\section{Resultados e Discussão}

No PD a flora de Vochysiaceae é composta por 22 espécies incluídas em quatro gêneros. O gênero com maior número de espécies é Vochysia (13), seguido de Qualea (5), Callisthene (3) e Salvertia, gênero monotípico representado por Salvertia convallariodora A.St.-Hil. Dentre estas, nove espécies apresentam distribuição mais restrita: Q. elegans Taub. ex Benoist e Vochysia sp., endêmicas do município de Diamantina; $C$. erythroclada Warm., endêmica da região do PD e norte da Serra do Cipó; $V$. pygmaea Bong. e $V$. rotundifolia Mart., endêmicas da Serra do Cipó e do PD, sendo pouco frequentes nesta última localidade; $V$. discolor Warm., endêmica do PD, Serra do Cabral e Serra do Cipó; $V$. acuminata Bong. e V. emarginata (Vahl) Poir., sendo a primeira endêmica da Cadeia do Espinhaço e a segunda predominantemente distribuída na região; $V$. dasyantha Warm., encontrada em Minas Gerais e Rio de Janeiro. As outras 13 espécies apresentam distribuição mais ampla, ocorrendo entre $2^{\circ} \mathrm{N} \mathrm{e}$ $27^{\circ} \mathrm{S}$, predominantemente em áreas de Cerrado e, às vezes, de Floresta Atlântica. São elas: $C$. major Mart., C. microphylla Warm., Q. cordata
Spreng., Q. grandiflora Mart., Q. multiflora Mart., Q. parviflora Mart., S. convallariodora, $V$. elliptica Mart., V. gardneri Warm., V. oppugnata (Vell.) Warm., V. rufa Mart., V. thyrsoidea Pohl e V. tucanorum Mart.

Dentre as 22 espécies encontradas no PD, quatro estão citadas no livro "Plantas Raras do Brasil" (França 2009) e tiveram o risco de extinção avaliado (Shimizu et al. 2014). São elas: Callisthene erythroclada, Qualea elegans, Vochysia pygmaea e $V$. rotundifolia. Uma nova espécie de Vochysia, chamada aqui de Vochysia sp., foi encontrada apenas próximo a Mendanha (Diamantina) e se soma a essa lista, já que até o momento foi coletado apenas um indivíduo.

\section{Tratamento taxonômico}

Vochysiaceae A.St.-Hil.

Árvores, arbustos, raramente subarbustos; ramos cilíndricos a quadrangulares, casca descamante em placas ou não. Folhas simples, inteiras, pecioladas ou subsésseis, de filotaxia oposta ou verticilada; estípulas decíduas ou persistentes, às vezes associadas a glândulas; venação broquidódroma ou reticulada; lâmina glabra ou com indumento variado. Inflorescências tirsos, terminais e/ou subterminais, eventualmente cíncinos unifloros ou sinflorescências complexas de arquitetura predominantemente tirsoide; eixos, pedúnculos, pedicelos, brácteas e bractéolas glabros ou indumentados; brácteas e bractéolas decíduas ou persistentes. Flores vistosas, diclamídeas, zigomorfas; cálice gamossépalo, pentâmero, com cálcar reto, incurvo ou recurvo, e quando não se desenvolve é representado apenas por uma protuberância bursiforme (Qualea subg. Amphilochia); corola dialipétala com uma, três ou cinco pétalas, de coloração branca, amarela ou lilás, com máculas presentes ou não, glabras ou indumentadas. Estame 1, persistente ou caduco na antese; antera biteca, oblonga ou deltoide, dorsifixa ou basifixa; estaminódios comumente presentes, petaloides. Ovário súpero, piramidal, globoso ou subgloboso, tricarpelar, trilocular, placentação axilar; estilete único, clavado ou cilíndrico, estigma simples, terminal, subterminal ou lateral. Fruto capsular loculicida, globoso, subgloboso, elipsoide, ovoide ou oblongo, com exocarpo íntegro ou quebradiço, columela central engrossada ou fina e quebrável durante a deiscência do fruto, às vezes ausente, região central das valvas livre ou fundida após a deiscência do fruto; semente circular ou unilateralmente alada. 


\section{Chave para identificação dos gêneros de Vochysiaceae no Planalto de Diamantina}

1. Folhas opostas dísticas, dispostas em râmulos filomórficos, catáfilos presentes na base dos râmulos; fruto maduro com exocarpo corticoso e quebradiço com columela central engrossada e persistente após a deiscência; sementes circularmente aladas 1. Callisthene

1'. Folhas opostas cruzadas, verticiladas, raro sub-alternas, não dispostas em râmulos filomórficos, catáfilos ausentes na base dos râmulos; fruto maduro com exocarpo lenhoso e não quebradiço, columela central ausente ou, se presente, delgada, podendo quebrar-se durante a deiscência; sementes unilateralmente aladas.

2. Estípulas com glândulas axilares associadas; flores com uma pétala; no fruto aberto, valvas livres, não fundidas na região central 2. Qualea

2'. Estípulas sem glândulas axilares associadas; flores com três ou cinco pétalas; no fruto aberto, valvas parcial ou totalmente fundidas na região central

3. Filotaxia verticilada, folhas em verticilos 7-9-meros; flores com cinco pétalas brancas; durante a deiscência o fruto permanece com as valvas parcialmente fundidas (no terço basal)

3. Salvertia

3'. Filotaxia oposta ou verticilada, neste caso, folhas em verticilos 3-5-meros; flores com três pétalas amarelas; durante a deiscência o fruto permanece com as valvas fundidas ou um pouco afastadas apenas na região apical.....

4. Vochysia

\section{Callisthene Mart.}

Árvores ou arbustos; ramos cilíndricos; casca não descamante em placas. Folhas opostas dísticas, dispostas em râmulos filomórficos (que se assemelham a uma folha pinada), râmulos com âmbito linear a estreito-oblongo ou obovadooblongo, catáfilos presentes na base dos râmulos, estípulas decíduas e sem glândulas associadas; pecioladas. Flores isoladas, axilares; brácteas decíduas, glabras ou indumentadas; botões florais retos, estreito-elípticos a elípticos, ápice agudo, subacuminado ou acuminado; flores com cálice calcarado, cálcar desenvolvido, reto, cilíndrico, aparente no botão floral, indumentado; pétala 1 , oposta ao lobo do cálice calcarado, branca com mácula amarela na região central, glabra, margem inteira, não ondulada, persistente na antese. Estame fora do plano de simetria da flor, persistente na antese, estaminódios ausentes, antera oblonga, basifixa. Ovário com muitos óvulos por lóculo, ovoide a globoso, estilete cilíndrico, levemente incurvo, estigma terminal, não ligulado. Cápsula globosa, com exocarpo corticoso, frágil, quebradiço em fragmentos irregulares; columela central engrossada, persistente após a deiscência; região central das valvas livre após a deiscência. Sementes 1 a 2 por lóculo, circularmente aladas.

O gênero compreende 11 espécies distribuídas em áreas de cerrado e floresta, no Paraguai, Bolívia e, principalmente, no Brasil, onde há representantes de todas as entidades taxonômicas, sendo o Planalto
Central brasileiro a região que abriga o maior número de espécies (Stafleu 1952; Martins 1981, 1988; França 1996; Bueno et al. 2000). Stafleu (1952) reconheceu duas seções: Callisthene sect. Callisthene e C. sect. Cataphyllantha Stafleu, que se diferenciam principalmente porque esta apresenta râmulos com 2-5 pares de folhas de 3-17 $\mathrm{cm}$ de comprimento, enquanto os representantes da seção autonímica apresentam râmulos com 5-15 pares de folhas com 0,3-3(5) $\mathrm{cm}$ de comprimento. As três espécies encontradas no PD são incluídas em $C$. sect. Callisthene.

Callisthene e Qualea apresentam apenas uma pétala, o que os torna os gêneros mais semelhantes dentre aqueles que ocorrem no PD. As espécies de Callisthene podem ser distinguidas das de Qualea por apresentarem râmulos filomórficos e por não apresentarem glândulas axilares associadas às estípulas. Além disso, na área de estudo, as espécies de Callisthene têm pétala branca com mácula central amarela. As espécies de Qualea têm pétala lilás, às vezes com máculas brancas (Q. parviflora); amarela (Q. grandiflora); branca com nervuras amarelas (Q. elegans); branca com máculas magenta a púrpura e faixa amarela na porção central da pétala $(Q$. cordata); e branca com máculas magenta ou amarela com máculas púrpura (Q. multiflora). Assim como as espécies de Callisthene do PD, Q. elegans também apresenta pétalas brancas, mas estas medem ca. $7 \times 6 \mathrm{~cm}$, enquanto as pétalas de Callisthene são diminutas, medindo no máximo ca. $1,5 \times 1,6 \mathrm{~cm}$. 


\section{Chave para identificação das espécies de Callisthene no Planalto de Diamantina}

1. Râmulos filomórficos ferrugíneo-tomentosos, raramente subglabrescentes........1. Callisthene erythroclada

1'. Râmulos filomórficos glabros, pubérulos a raramente pubérulos ou glabrescentes, neste caso gríseos .....2

2. Râmulos em geral com 8-13 pares de folhas, com âmbito linear a estreito-oblongo; lâmina foliar $0,35-0,5 \times 0,25-0,3 \mathrm{~cm}$, nervuras secundárias não evidentes, nervura marginal ausente; pétala ca.

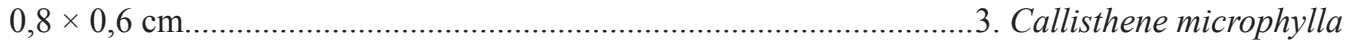

2'. Râmulos em geral com 3-8(12) pares de folhas, com âmbito obovado-oblongo; lâmina foliar 1,5-4,5 × 1-1,5 cm, nervuras secundárias evidentes, nervura marginal presente; pétala ca. 1,5 $\times$ $1,6 \mathrm{~cm}$ 2. Callisthene major

1.1. Callisthene erythroclada Warm. in Mart. \& Eichler, Fl. bras. 13(2): 28. $1875 . \quad$ Fig. 1a-g Ilustração: Shimizu \& Yamamoto (2012a).

Nome popular: tapicuru (D.J.P. Gonçalves et al. 438, UEC 165965)

Árvores ou arbustos, 2-6 m alt. Râmulos com 6-13 pares de folhas, com âmbito obovado-oblongo, ferrugíneo-tomentosos a raro subglabrescentes; pecíolo $0,5-1 \mathrm{~mm}$ compr., ferrugíneo-tomentoso; lâmina foliar $0,8-2,5 \times 0,4-0,9 \mathrm{~cm}$, cartácea, variando de orbicular na região proximal dos râmulos, a elíptica, ovada até lanceolada na região distal dos râmulos, ápice agudo, arredondado, até ligeiramente emarginado, com múcron presente ou não, base arredondada a subcordada, margem plana, ciliada, face adaxial glabra, raramente tomentosa a glabrescente, nervura primária plana ou promínula, face abaxial tomentosa a glabrescente, nervuras secundárias evidentes, nervura marginal presente. Pedúnculo e brácteas pilosos; botões florais ca. 7,5 × 2,5 mm, ápice agudo a subacuminado; sépala calcarada $5-6,8$ $\mathrm{mm}$ compr., ápice longo-acuminado, pubérula a glabrescente, sépalas laterais 2,7-3,7 × 0,7-2 mm, lanceoladas a subuladas, ápice longo-acuminado, pubérulas a glabrescentes; cálcar $0,5-1 \mathrm{~mm}$ compr., reto, pubérulo; pétala ca. $0,7 \times 1 \mathrm{~cm}$, obcordada, ápice emarginado, base atenuada, glabra. Estame 3-4,2 mm compr., filete 1,5-2,2 mm compr., antera 1,5-2 mm compr., glabra. Ovário 0,5-0,7 × 0,5-0,7 $\mathrm{mm}$, glabro; estilete $2,7-2,9 \mathrm{~mm}$ compr., glabro. Cápsula $0,7-1,3 \times 0,7-1,1 \mathrm{~cm}$, globosa, superfície lisa, glabra.

Material selecionado: Diamantina, próximo ao distrito de Mendanha, 18.XII.2003, fr., V.C. Souza et al. 29639 (ESA); 15.III.1970, fr., H.S. Irwin et al. 27557 (MO, NY, US); Boa Vista, 9.XI.1937, fl., H.L. Mello Barreto 9677 (BHCB, F, NY, SPF); Ponte do Acaba Mundo, 14.XII.2011, fr., D.J.P. Gonçalves et al. 321 (UEC); 21.XI.2011, fl. e fr., D.J.P. Gonçalves \& M.M.T. Cota 226 (UEC); Itamarandiba, Parque Estadual de Serra Negra, 27.II.2012, veg., D.J.P. Gonçalves et al. 479 (UEC); São Gonçalo do Rio Preto, Parque Estadual do Rio Preto,
8.IV.2000, fr., J.A. Lombardi et al. 3853 (SP); trilha para Cachoeira do Crioulo, 19.XI.2011, fl., D.J.P. Gonçalves et al. 202 (DIAM, UEC); próximo ao Parque Estadual do Rio Preto, 1.V.2012, fl. e fr., D.J.P. Gonçalves et al. 539 (UEC); Senador Modestino Gonçalves, 27.I.2012, fr., D.J.P. Gonçalves et al. 439 (DIAM, UEC); Serra do Ambrósio, 28.II.2011, veg., D.J.P. Gonçalves et al. 483 (UEC).

Material adicional examinado: Jaboticatubas, $\mathrm{Km}$ 117, 3.XI.1978, fl., J. Semir (UEC 52323, VIC 6281); Santa Luzia, Km 127, Palácio, 3.IX.1933, fr., H.L. Mello Barreto 8324 (BHCB, GUA); Santana do Riacho, Estrada da Usina, 10.XI.1980, fl. e fr., I. Cordeiro et al. CFSC 6777 (SP, SPF, UEC); Km 125, Córrego Três Pontinhas, 7.III.1992, fl., J.R. Pirani et al. CFSC 12902 (SPF, UEC).

Callisthene erythroclada apresenta distribuição restrita, ocorrendo no Planalto de Diamantina e na Serra do Cipó, sendo menos frequente nesta última localidade. Encontrada em cerrado rupestre, campo rupestre, floresta ciliar e raramente em cerrado s.s., geralmente em locais próximos à água ou entre rochas. Ocorre entre 690 e $1260 \mathrm{~m}$ de altitude. Na área de estudo foi coletada com flor em abril, maio e novembro, e com frutos de março a maio e de novembro a janeiro.

Dentre as espécies encontradas no PD, $C$. erythroclada pode ser reconhecida por ser a única a apresentar indumento de coloração ferrugínea nos râmulos filomórficos. No PD as dimensões das folhas de C. erythroclada variam de acordo com o hábitat. Indivíduos coletados em florestas apresentam folhas com dimensões maiores quando comparados às folhas de indivíduos coletados em áreas de campo ou cerrado. Os indivíduos de áreas florestais se assemelham a $C$. major, da qual se diferenciam por apresentarem folhas cartáceas, enquanto as folhas de C. major são coriáceas, principalmente as mais velhas. Além disso, as dimensões da pétala, do estame e do estilete são menores em $C$. erythroclada. Indivíduos provenientes de áreas abertas se assemelham a C. microphylla, da qual pode ser distinta por 
apresentar folhas com nervuras secundárias conspícuas e nervura marginal presente, enquanto C. microphylla apresenta nervuras secundárias inconspícuas ou subconspícuas e nervura marginal ausente. A coloração dos ramos mais jovens também pode ajudar no reconhecimento das duas espécies, sendo que em C. erythroclada esses ramos têm coloração avermelhada e em C. microphylla os ramos jovens possuem coloração acinzentada.

1.2. Callisthene major Mart., Nov. Gen. Sp. Pl. 1: 124, t. 75.1826.

Fig. 1h-n

Ilustração: Yamamoto (2009), Shimizu \& Yamamoto (2012a), Gonçalves et al. (2013).

Nome popular: pau-terra (Stafleu 1952).

Árvores ou arbustos, 1,5-4 m alt. Râmulos com 3-8(-12) pares de folhas, com âmbito obovadooblongo, glabros, raramente gríseo-pubérulos a glabrescentes; pecíolo 0,6-2 mm compr., glabro, raro gríseo-pubérulo a glabrescente; lâmina foliar 1,5-4,5 × 1-1,5 cm, coriácea, variando de oblonga na região proximal a lanceolada na região distal dos râmulos, ápice agudo, arredondado ou emarginado, com múcron presente ou não, base arredondada a subcordada, margem plana, ciliada, face adaxial glabra, nervura primária plana, face abaxial glabra, nervuras secundárias evidentes, nervura marginal presente. Pedúnculo e brácteas glabros; botões florais 7-8 $\times 2-3 \mathrm{~mm}$, ápice agudo; sépala calcarada $7-11 \mathrm{~mm}$ compr., ápice obtuso a arredondado, pubescente a glabrescente, sépalas laterais 3,8-5,4 × 1,7-2,3 mm, lanceoladas, ápice agudo a acuminado, tomentosas; cálcar 1,3-1,7 $\mathrm{mm}$ compr., reto, pubérulo; pétala ca. 1,5 × 1,6 $\mathrm{cm}$, obcordada, ápice emarginado, base atenuada, glabra. Estame 8-9 mm compr., filete 5-5,5 $\mathrm{mm}$ compr., antera 3-3,6 mm compr., glabra. Ovário ca. $0,7 \times 0,7 \mathrm{~mm}$, glabro; estilete ca. $7 \mathrm{~mm}$ compr., glabro. Cápsula $0,8-1,3 \times 0,7-1 \mathrm{~cm}$, globosa, superfície lisa, glabra.

Material examinado: Datas, Rodovia Guinda - Conceição do Mato Dentro, 18.III.1985, veg., G. Hatschbach et al. 51100 (US); Diamantina, $10 \mathrm{~km}$ da rodovia Curvelo Diamantina, 10.IV.1995, fr., R. Mello-Silva et al. 1047 (SP); estrada para Biri-Biri, 8.XII.1992, veg., H.F. Leitão Filho et al. 27377 (UEC); Costa Sena, 15.IX.1985, fl., G. Hatschbach \& R. Kummrow 49720 (MBM, US); Mendanha, 13.IV.1973, fr., W.R. Anderson 8817 (MO, NY); Estrada Guinda - Conselheiro Mata, 4.VI.1985, fr., F.R. Martins et al. 17139 (UEC); 4.VI.1985, fr., H.F. Leitão Filho et al. 17343 (UEC); Gouveia, 10.XII.2011, fr., D.J.P. Gonçalves \& M.M.T. Cota 249 (DIAM, UEC); 10.XII.2011, fr., D.J.P. Gonçalves \& M.M.T. Cota 250 (DIAM, UEC); São Gonçalo do Rio Preto, Parque
Estadual do Rio Preto, 17.XI.1999, fr., J.A. Lombardi 3440 (SP); 18.XI.2011, fr., D.J.P. Gonçalves et al. 186 (DIAM, UEC); 18.XI.2011, fr., D.J.P. Gonçalves et al. 187 (DIAM, UEC).

Material adicional examinado: Araguari, 26.IX.2012, fl., A.F.A. Versiane et al. 260 (HUFU, UEC); Francisco Dumont, 23.VIII.2002, fl., G. Hatschbach et al. 73781 (UEC); Grão Mogol, 26.II.2011, fr., D.J.P. Gonçalves et al. 464 (UEC).

Callisthene major é uma espécie amplamente distribuída no cerrado brasileiro, ocorrendo na BA, GO, MG, MS, MT, PR, TO e DF. No Planalto de Diamantina, ocorre entre 698 e 1029 m de altitude e é encontrada em floresta ciliar, cerrado rupestre e cerrado, geralmente em locais próximos a cursos d'água. Coletada com flores em agosto e setembro e com frutos em fevereiro, abril, junho, novembro e dezembro. Dentre as espécies do gênero na área de estudo, esta é a que apresenta, em geral, menor número de folhas por râmulo e maior dimensão de folhas, flores e frutos. Além disso, folhas coriáceas a distinguem de $C$. erythoclada, que possui folhas cartáceas, e a presença de nervura marginal nas folhas a distingue de $C$. microphylla, que não possui essa nervura. Callisthene major possui duas variedades, a variedade típica e $C$. major var. pilosa Warm., esta caracterizada pela presença de indumento, principalmente na face abaxial das folhas. A presença/ausência de indumento pode variar bastante dentro da mesma espécie, e sob este ponto de vista, não consideramos categorias infra-específicas. Embora seja possível encontrar espécimes com indumento presente ou ausente em uma mesma localicade, no PD foram encontrados apenas indivíduos glabros.

1.3. Callisthene microphylla Warm. in Mart. \& Eichler, Fl. bras. 13(2): 28, t. 3, fig. 1. 1875.

Fig. 2a-i

Ilustração: Shimizu \& Yamamoto (2012a).

Nome popular: vassourinha (BFG 2015).

Árvores ou arbustos, 1,5-3 m alt. Râmulos com (4-)8-13 pares de folhas, com âmbito linear a estreito-oblongo, glabros ou gríseo-pubérulos a glabrescentes; pecíolo $0,6-0,8 \mathrm{~mm}$ compr., gríseopubérulo; lâmina foliar $0,35-0,5 \times 0,25-0,3 \mathrm{~cm}$, cartácea, variando de orbicular na região proximal dos râmulos, a oblonga, até lanceolada na região distal dos râmulos, ápice retuso, truncado, obtuso ou agudo, com múcron presente ou não, base arredondada, margem plana, minutamente ciliada, face adaxial glabra, raramente pubérula, nervura primária plana ou promínula, face abaxial glabra, nervuras secundárias não evidentes, nervura marginal ausente. Pedúnculo 


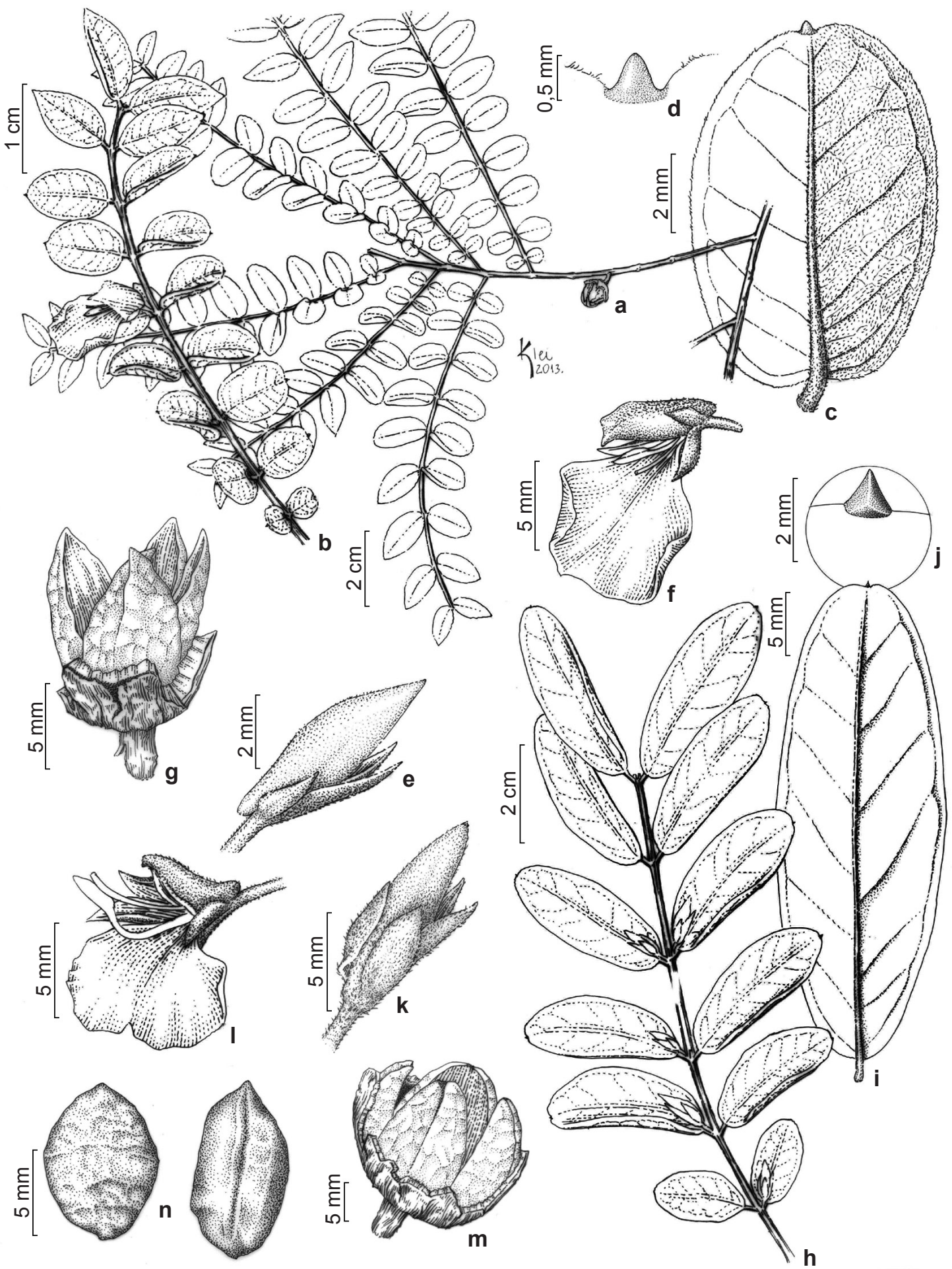

Figura 1 - a-g. Callisthene erythroclada Warm. - a. ramo; b. râmulo; c. face abaxial da folha; d. detalhe do múcron no ápice da folha; e. botão floral; f. flor; g. fruto. h-n. Callisthene major Mart. - h. râmulo; i. face abaxial da folha; j. detalhe do múcron no ápice da folha; k. botão floral; 1. flor; m. fruto; n. sementes.

Figure 1 - a-g. Callisthene erythroclada Warm. - a. branch; b. branchlet; c. abaxial surface of leaf; d. detail of the mucron on the leaf apex; e. flower bud; f. flower; g. fruit. h-n. Callisthene major Mart. - h. branchlet; i. abaxial surface of leaf; j. detail of the mucron on the leaf apex; $k$. flower bud; 1 . flower; $m$. fruit; $n$. seeds. 


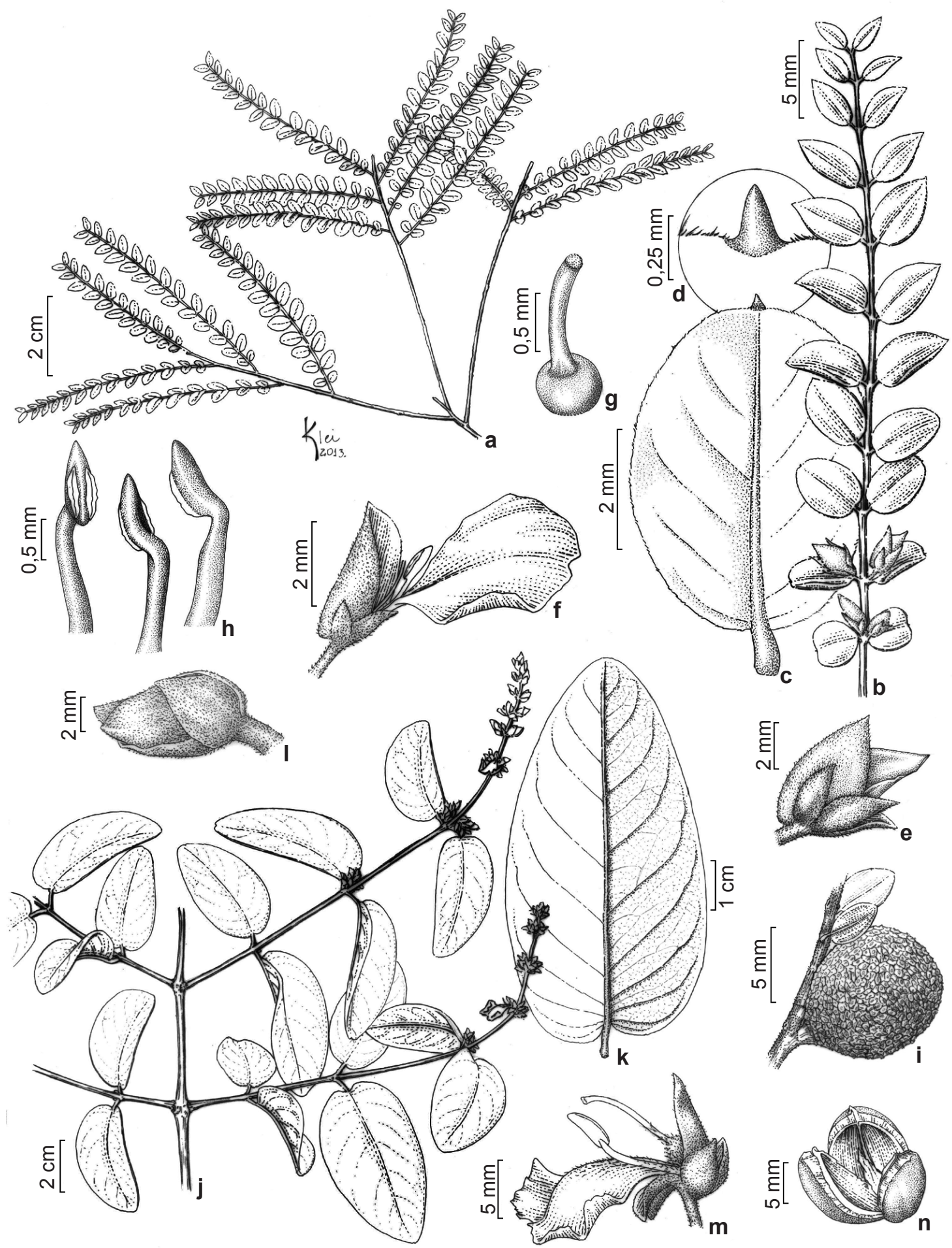

Figura 2 - a-i. Callisthene microphylla Warm. - a. ramo; b. râmulo; c. face abaxial da folha; d. detalhe do múcron no ápice da folha; e. botão floral; f. flor; g. gineceu; h. estame em algumas vistas; i. fruto. j-n. Qualea cordata Spreng. - j. ramo; k. face abaxial da folha; 1 . botão floral; $m$. flor; $n$. fruto.

Figure 2 - a-i. Callisthene microphylla Warm. - a. branch; b. branchlet; c. abaxial surface of leaf; d. detail of the mucron on the leaf apex; e. flower bud; f. flower; g. gynoecium; h. stamen in some views; i. fruit. j-n. Qualea cordata Spreng. - j. branch; k. abaxial surface of leaf; 1 . flower bud; $m$. flower; $n$. fruit. 
e brácteas pilosos; botões florais 3,5-5 × 1,5-2 $\mathrm{mm}$, ápice agudo a acuminado; sépala calcarada 4,5-6,5 mm compr., ápice apiculado, pubérulo, sépalas laterais 1,6-2 ×0,4-0,6 mm, lanceoladas a largo-lanceoladas, ápice agudo a longo-acuminado, pubérulas; cálcar $0,5-0,6 \mathrm{~mm}$ compr., reto, pubérulo; pétala ca. $0,8 \times 0,6 \mathrm{~cm}$, obcordada, ápice emarginado, base atenuada, glabra. Estame 2,5-3 mm compr., filete $1,5-2 \mathrm{~mm}$ compr., antera $1-1,3$ mm compr., glabra. Ovário $0,5-0,8 \times 0,5-0,8 \mathrm{~mm}$, glabro; estilete 1,8-2,9 mm compr., glabro. Cápsula $0,8-1 \times 0,7-0,9 \mathrm{~cm}$, globosa, superfície lisa, glabra. Material examinado: São Gonçalo do Rio Preto, Parque Estadual do Rio Preto, 17.XI.1999, fl., J.A. Lombardi 3366 (SPF); 18.XI.2011, fl. e fr., D.J.P. Gonçalves et al. 199 (DIAM, UEC); heliporto, 18.XI.2011, fl. e fr., D.J.P. Gonçalves et al. 200 (DIAM, UEC); trilha para Cachoeira do Crioulo, 19.XI.2011, fl., D.J.P. Gonçalves et al. 210 (DIAM, UEC); 19.XI.2011, fl., D.J.P. Gonçalves et al. 218 (DIAM, UEC); 1.V.2012, fr., D.J.P. Gonçalves et al. 546 (UEC).

Callisthene microphylla é amplamente distribuída no Brasil Central, tendo registros na BA, CE, GO, MA, MG, PA, PI e TO, encontrada em cerrados, campos e carrascos (Stafleu 1952; Martins 1981). No PD é encontrada principalmente em campo e cerrado rupestres, mas também pode ser encontrada em capão e em cerrado s.s., em locais associados a cursos d'água ou entre rochas. $\mathrm{Na}$ área de estudo ocorre entre 693 e $938 \mathrm{~m}$ de altitude, onde foi coletada com flores em novembro e com frutos em maio e novembro.

Além das características apresentadas nos comentários de $C$. erythroclada e de C. major, $C$. microphylla também pode ser reconhecida pelo âmbito dos râmulos linear a estreito-oblongo (Fig. $2 b$ ), que geralmente possuem a mesma largura na região proximal, na região mediana e na região distal. Isto ocorre devido à relativa uniformidade do tamanho das folhas ao longo dos râmulos. Em C. erythroclada (Fig. 1b) e C. major (Fig. 1h) as folhas têm uma maior variação de tamanho, apresentando râmulo de âmbito obovado-oblongo, ou seja, a porção distal do râmulo é mais larga, a porção mediana é um pouco mais estreita e a porção proximal é ainda um pouco mais estreita.

\section{Qualea Aubl.}

Árvores ou arbustos; ramos cilíndricos ou subquadrangulares, estes geralmente em partes jovens, casca descamante em placas ou não. Folhas opostas cruzadas, raramente em verticilos 3-meros ou sub-alternas, não dispostas em râmulos filomórficos, catáfilos ausentes, estípulas decíduas e com glândulas crateriformes associadas; pecioladas. Inflorescências tirsos terminais e subterminais ou sinflorescências complexas de arquitetura predominantemente tirsoide, compostos por cíncinos opostos, alternos, sub-alternos ou verticilados na porção distal do eixo da inflorescência; brácteas e bractéolas decíduas; botões florais retos, ovoides, ápice agudo, acuminado ou longo-acuminado; flores com cálice calcarado ou não, cálcar representado por uma protuberância bursiforme, pouco desenvolvido ou desenvolvido, reto, incurvo ou recurvo, cilíndrico ou clavado, aparente ou escondido entre as sépalas não calcaradas no botão floral, indumentado; pétala 1, oposta ao lobo do cálice calcarado, branca, amarela ou lilás, com máculas presentes ou não, glabra a tomentosa, margem inteira, ondulada, persistente na antese. Estame fora do plano de simetria da flor, persistente na antese; estaminódios ausentes, antera deltoide ou oblonga, dorsifixa ou basifixa. Ovário com 2 a 12 óvulos por lóculo, ovoide, estilete cilíndrico, raramente clavado, levemente incurvo, estigma terminal, não ligulado. Cápsula ovoide ou oblonga, com exocarpo lenhoso, não quebradiço; columela central, se presente, livre e delgada, podendo quebrar-se durante a deiscência; região central das valvas livre após a deiscência. Sementes 2 a 12 por lóculo, unilateralmente aladas.

O gênero compreende 50 espécies distribuídas nas Américas Central e do Sul, dentre as quais 37 possuem registros em florestas tropicais e savanas do Brasil (BFG 2015). Stafleu (1953) reconheceu os subgêneros Qualea (seções Trichanthera Stafleu, Qualea, Costatifolium Stafleu e Polytrias Stafleu) e Amphilochia (Mart.) Stafleu. Qualea seção Trichanthera foi elevada a gênero por Marcano-Berti (1969), que o chamou Ruizterania Marc.-Berti, mas estudos moleculares e anatômicos não sustentam esta classificação (p. ex. Litt 1996; Sajo \& Rudall 2002). Como o gênero Ruizterania ainda não foi sinonimizado optamos por não contabilizar as espécies da seção Trichanthera (14 spp.) no gênero Qualea.

No PD foram encontradas cinco espécies de Qualea subg. Qualea incluídas em $Q$. sect. Qualea (1 sp.) e $Q$. sect. Costatifolium (3 spp.) e uma espécie de $Q$. subg. Amphilochia. As espécies de Qualea podem ser distinguidas das outras Vochysiaceae principalmente pelas glândulas nas axilas das estípulas decíduas, pelas folhas não dispostas em râmulos filomórficos, pela filotaxia quase sempre oposta cruzada, pelos botões florais ovoides, e pelos frutos que após a deiscência ficam com as valvas livres, não fundidas na região central. 


\section{Chave para identificação das espécies de Qualea no Planalto de Diamantina}

1. Nervuras secundárias que terminam em arcos próximo à margem da lâmina, sem formar a nervura marginal contínua; cálice sem cálcar desenvolvido, representado apenas por uma protuberância bursiforme.

1'. Nervuras secundárias dispostas paralelamente formando uma nervura marginal contínua; cálice com cálcar desenvolvido.

2. Cálcar escondido pelas sépalas não calcaradas no botão floral; pétala $3,9-7 \times 4,7-6 \mathrm{~cm} \ldots \ldots \ldots \ldots . .3$

2'. Cálcar aparente no botão floral, não escondido pelas sépalas não calcaradas; pétalas $1-3,5 \times$ $0,7-2,6 \mathrm{~cm}$.

3. Ramos com casca não descamante em placas; pecíolo 4-5,5 mm compr.; folhas com 14-15 nervuras secundárias por centímetro de comprimento, nervura primária com alas laterais na face abaxial; ápice dos botões florais longo-acuminados e apiculados; cálcar ca. $6 \mathrm{~mm}$ compr., reto......

2. Qualea elegans

3'. Ramos com casca descamante em placas; pecíolo 5-15 mm compr.; folhas com 3-5 nervuras secundárias por centímetro de comprimento, nervura primária sem alas laterais na face abaxial; ápice dos botões florais agudos, mas nunca apiculados; cálcar 1,9-2,3 cm compr., incurvo.....

3. Qualea grandiflora

4. Inflorescências com indumento ferrugíneo a ocráceo; pétala branca com máculas magenta ou amarela com máculas púrpura; cápsula com superfície não descamante.

4. Qualea multiflora

4'. Inflorescências com indumento pubescente a canescente; pétala lilás, às vezes com linha central ou máculas alvas; cápsula com superfície descamante ...... 5. Qualea parviflora

2.1. Qualea cordata Spreng., Syst. Veg. (ed. 16) 1: 17. 1824.

Fig. $2 \mathrm{j}-\mathrm{n}$

Ilustração: Yamamoto (2009), Shimizu \& Yamamoto (2012a), Gonçalves et al. (2013).

Nomes populares: dedaleira-preta, pau-terra (Brasil), quebracho-falso, burro-caá (Paraguai) (Stafleu 1953).

Árvores ou arbustos, 1,5-4 m alt. Ramos cilíndricos ou subquadrangulares, glabros, casca não descamante em placas. Folhas opostas cruzadas, pecíolo 3-9 mm compr., glabro, raro glabrescente; lâmina foliar 2,5-10 × 2-4,5 cm, cartácea a coriácea, ovada, elíptica até suboblonga, raramente estreito-elíptica, ápice obtuso, arredondado ou agudo, base cordada ou subcordada, margem plana, face adaxial glabra, raramente pubérula ou glabrescente, nervura primária impressa, face abaxial glabra, raramente tomentosa a glabrescente, nervura primária proeminente, não alada, nervuras secundárias que terminam em arcos próximos à margem, proeminentes, ca. 2 por $\mathrm{cm}$ compr., nervura marginal ausente. Inflorescências 4,5-18 cm compr., tirsos terminais e subterminais, com cíncinos 1-3-floros, opostos cruzados, eixo glabro, pedúnculos, pedicelos, brácteas e bractéolas ferrugíneo-tomentosos; brácteas e bractéolas decíduas. Botões florais 5-7 × 3,3-5 mm, ápice agudo; sépalas externa e internamente creme esverdeadas a avermelhadas, sépala com protuberância bursiforme $7-13 \mathrm{~mm}$ compr., ápice agudo a arredondado, pubescente, sépalas não calcaradas 4-6×3-4 cm, ovadas, ápice arredondado a obtuso, pubescentes; cálcar não desenvolvido, representado por uma protuberância bursiforme, no botão floral fica escondido entre as sépalas não calcaradas, pubescente; pétala $0,9-1,5$ $\times 1,1-1,4 \mathrm{~cm}$, branca com máculas magenta a púrpura, obcordada, ápice emarginado, base atenuada, tomentosa na face adaxial, margem inteira, ondulada. Estame 8-9 $\mathrm{mm}$ compr., filete 4,5-7 mm compr., antera 3,5-4,6 $\mathrm{mm}$ compr., basifixa, oblonga, reta, glabra. Ovário 4-5 × 2-3 $\mathrm{mm}$, seríceo; estilete 4-8 mm compr., cilíndrico, seríceo na base. Cápsula 2-3 $\times 1-1,5 \mathrm{~cm}$, ovoide, superfície levemente verruculosa, não descamante, tomentosa.

Material selecionado: Couto de Magalhães de Minas, 22.VI.2002, fl., F.N. Costa et al. 590 (SPF); Datas, entre o trevo e Datas, 12.XII.2011, fr., D.J.P. Gonçalves et al. 281 (UEC); 12.XII.2011, fl., D.J.P. Gonçalves et al. 283 (UEC); Diamantina, Barão do Guaicuí, 24.X.1999, fl., G. Hatschbach et al. 69666 (SP); próximo ao distrito de Mendanha, 18.XII.2003, fr., V.C. Souza et al. 29633 (ESA); Mendanha, 17.IX.1985, fl., G. Hatschbach \& F.J. Zelma 49820 (US); Estrada Diamantina - Biribiri, 15.X.1984, fl., E. Isejima et al. CFCR 5533 (NY, SP, SPF, US); 25.IX.2008, fl., F.N.A. Mello et al. 472 (UEC); 31.X.1981, fl., A.M. Giulietti et al. CFCR 2470 (SPF, UEC); 18.XI.1984, fl., R.M. Harley et al. CFCR 6155 
(NY, SP, SPF, UEC); 19.X.2007, fl., F.N.A. Mello et al. 38 (HUFU, UEC); 27.VI.2011; fr., D.J.P. Gonçalves et al. 112 (DIAM); 14.III.1970, fr., H.S. Irwin et al. 27496 (NY, US); 27.IX.1995, fl. e fr.; A. Salatino et al. 85 (SPF); 27.VI.1995, fr., A. Salatino et al. 36 (SPF); Estrada Diamantina - Extração, 29.X.1981, fl., A.M. Giulietti et al. (SPF 21054, UEC 152906); Estrada Gouveia Curvelo, 23.IX.2008, fl., R. Romero et al. 8114 (HUFU, UEC); Estrada Sopa - São João da Chapada, 15.XI.2011, fl., D.J.P. Gonçalves \& M.M.T. Cota 147 (UEC); Estrada Mendanha, 16.XI.2011, fl., D.J.P. Gonçalves \& M.M.T. Cota 153 (UEC); Estrada Mendanha - Inhaí, 16.XI.2011, fr., D.J.P. Gonçalves \& M.M.T. Cota 159 (UEC); 28.IV.2012, fr., D.J.P. Gonçalves et al. 512 (UEC); Estrada Diamantina - São Gonçalo do Rio das Pedras, 21.XI.2011, fl., D.J.P. Gonçalves \& M.M.T. Cota 221 (UEC); Estrada Curralinho, 23.XI.2011, fl., D.J.P. Gonçalves 236 (UEC); Estrada Curralinho - Acaba Mundo, 24.XI.2011, fr., D.J.P. Gonçalves \& M.M.T. Cota 242 (UEC); 14.XII.2011, fr., D.J.P. Gonçalves et al. 319 (UEC); Parque Nacional das Sempre Vivas, 16.XII.2011, fr., D.J.P. Gonçalves et al. 349 (UEC). Conselheiro Mata, 22.I.2012, fr., D.J.P. Gonçalves et al. 380 (UEC); Estrada Rodeador - Conselheiro Mata, 24.I.2012, fr., D.J.P. Gonçalves et al. 410 (DIAM, UEC); Estrada Diamantina - Milho Verde, 30.IV.2012, fr., D.J.P. Gonçalves et al. 532 (UEC); Estrada Conselheiro Mata - Diamantina, 20.X.2007, fl., J.N. Nakajima et al. 4665 (HUFU, UEC); 20.X.2007, fl., J.N. Nakajima et al. 4671 (UEC, HUFU); Estrada Telésforo, 21.X.2007, fl., P.O. Rosa et al. 946 (HUFU, UEC); Estrada Gouveia - Curvelo, 23.IX.2008, fl., J.N. Nakajima et al. 4968 (HUFU, UEC); Estrada Diamantina - Curvelo, 23.X.2008, fl., P.O. Rosa et al. 1150 (UEC); Gouveia, Hotel Chapéu do Sol, 19.XII.1959, fr., B. Maguire et al. 44687 (NY, US). Engenho do Bilia, 23.IX.1998, fl., M.M.N. Braga et al. (BHCB 47139, ESA 65994, SP 340266, SPF 140598); estrada entre Gouveia - Cuiabá, 10.XII.2011, fr., D.J.P. Gonçalves \& M.M.T. Cota 257 (UEC); Estrada Barão de Guaicuí, 13.XII.2011, fr., D.J.P. Gonçalves et al. 307 (UEC); São Gonçalo do Rio Preto, Parque Estadual do Rio Preto, 10.VI.1999, fr., A. Salino 4762 (SP); 17.XI.1999, fr., J.A. Lombardi 3394 (SP); 18.XI.1999, fl., J.A. Lombardi 3480 (SP); estrada para o sanitário, 23.VI.2011, fr., D.J.P. Gonçalves et al. 102 (DIAM, UEC); próximo à casa dos vigilantes, 17.XI.2011, fr., D.J.P. Gonçalves et al. 169 (UEC); trilha para Cachoeira do Crioulo, 19.XI.2011, fr., D.J.P. Gonçalves et al. 208 (UEC); 19.XI.2011, fl., D.J.P. Gonçalves et al. 220 (UEC); 1.V.2012, fr., D.J.P. Gonçalves et al. 540 (UEC).

Qualea cordata é amplamente distribuída em cerrado s.s. e outras formações savânicas adjacentes, ocorrendo na Argentina, Bolívia, Paraguai e no Brasil, onde possui registros nos estados de BA, ES, GO, MG, MT, PR, SC, SP e no DF (Yamamoto 2009; Gonçalves et al. 2013). No PD ocorre entre 600 e 1448 m de altitude, em campos e cerrados rupestres, cerrados e raramente em capões, geralmente em locais próximos a cursos d'água. Coletada com flores em junho e de setembro a novembro e com frutos em janeiro, fevereiro, de abril a junho e de outubro a dezembro.

Qualea cordata é a única espécie do gênero que ocorre no PD cujo cálcar não é desenvolvido, sendo representado apenas por uma protuberância bursiforme. Dentre as espécies de Qualea, esta pode ser reconhecida por apresentar folhas com nervuras secundárias que formam arcos que terminam próximo à margem da folha sem formar nervura marginal. As outras quatro espécies do gênero que ocorrem na área, $Q$. elegans, $Q$. grandiflora, Q. multiflora e Q. parviflora, possuem nervuras costadas que se anastomosam em uma nervura marginal localizada próximo à margem da folha. Além disso, Q. cordata é a única a apresentar pétala tomentosa na face adaxial.

Devido à significativa variação morfológica e à sobreposição de caracteres diagnósticos, Q. cordata e Q. dichotoma (Mart.) Warm. formam um complexo e a classificação destas entidades tem sofrido várias alterações desde a publicação das descrições originais. No PD ocorre apenas $Q$. cordata var. cordata, segundo a delimitação proposta por Yamamoto (2009), contudo, encontramos indivíduos que apresentam pecíolos maiores que $5 \mathrm{~mm}$, tamanho máximo considerado pela autora para variedade típica.

2.2. Qualea elegans Taub. ex Benoist, Notul. Syst. (Paris) 3: 177. 1915.

Fig. 3a-h

Árvores, ca. $5 \mathrm{~m}$ alt. Ramos cilíndricos ou quadrangulares, pubescentes a glabrescentes, casca dos ramos não descamante em placas. Folhas opostas cruzadas, pecíolo 4-5,5 mm compr., pubescente a glabrescente; lâmina foliar 6-7,8 $\times 5,5-6 \mathrm{~cm}$, cartácea a coriácea, oblonga, ovada ou largo elíptica, ápice curto-acuminado, base cordada ou subcordada, margem plana, face adaxial glabra, nervura primária subimpressa ou plana, face abaxial pubescente, nervura primária proeminente, lateralmente alada, com alas tomentosas, nervuras secundárias paralelas, promínulas, $14-15$ por $\mathrm{cm}$ de compr., nervura marginal presente. Inflorescências ca. 12,5 cm compr., tirsos terminais, com cíncinos unifloros opostos, eixo, pedúnculos, pedicelos e brácteas ferrugíneo-tomentosos. Botões florais 2,5-4,2 × 1,2-1,5 cm, ápice longo-acuminado, apiculado; sépala calcarada ca. $3 \mathrm{~cm}$ compr., ápice profundamente emarginado, seríceo, sépalas não calcaradas 8-12 × 7-13 mm, ovadas, ápice obtuso 
a arredondado, seríceo; cálcar ca. $6 \mathrm{~mm}$ compr., pouco desenvolvido, clavado, reto, no botão floral fica escondido entre as sépalas não calcaradas, seríceo; pétala ca. $7 \times 6 \mathrm{~cm}$, branca com nervuras amarelas, obcordada, ápice emarginado, base atenuada, glabra, margem inteira, ondulada. Estame ca. 2,5 cm compr., filete ca. 1,3 mm compr., antera ca. 1,2 mm compr., basifixa, deltoide, curvada, glabra. Ovário ca. $5 \times 4 \mathrm{~mm}$, tomentoso; estilete ca. 1,6 cm compr., clavado, glabro, seríceo na base. Frutos desconhecidos.

Material examinado: Diamantina, 8.IX.1971, fl., G. Hatschbach 27434 (MBM); 16.II.1973, fl., G. Hatschbach \& Z. Ahumada 31642 (MBM, NY, UEC); 14.IV.1973, fl., W.R. Anderson et al. 8853 (MBM, NY); 19.III.1987, fl., G. Hatschbach et al. 51115 (MBM, NY, UPCB).

Qualea elegans foi descrita no início do século XX e até hoje é uma espécie pouco conhecida, sendo seus frutos desconhecidos (Stafleu 1953). O material-tipo é proveniente do Parque Estadual do Biribiri e, além deste, existem poucas coletas provenientes apenas da região da cidade de Diamantina, quase sempre sem precisão quanto à localidade da coleta. Durante as expedições realizadas neste trabalho, foram feitas buscas às localidades descritas nas etiquetas e não foram encontrados indivíduos pertencentes a esta espécie em nenhum local do PD. Antigos moradores informaram que na região havia uma serra chamada Serra dos Cristais, nome similar à "Salto Cristal" (encontrado como localidade de coleta em Hatschbach et al. 51115), mas esta serra foi destruída alguns anos atrás pelo avanço da cidade.

Qualea elegans assemelha-se às espécies amazônicas do gênero principalmente pelas nervuras secundárias paralelas e numerosas. No PD é a única espécie de Qualea seção Qualea, grupo de ocorrência predominantemente amazônica. Coletada com flores em fevereiro, março, abril e setembro e, como apresentado acima, ainda não foi coletada com frutos. Ocorre em áreas de campo rupestre, capão e mata ciliar.

2.3. Qualea grandiflora Mart., Nov. Gen. Sp. Pl. 1: 133.1826.

Fig. 4a-e

Ilustração: Yamamoto (2009), Shimizu \& Yamamoto (2012a), Gonçalves et al. (2013).

Nomes populares: pau-terra, pau-terra-uassú, pau-terra-do-campo, pau-terra-de-folha-larga, pausanto, árvore-da-terra, uva-puva-do-campo, ariuaú (PA) (Stafleu 1953).
Árvores, 1,5-6,5 m alt. Ramos cilíndricos ou quadrangulares em partes jovens, pubescentes a glabrescentes, casca dos ramos descamante em placas. Folhas opostas cruzadas, pecíolo 5-15 mm compr., tomentoso; lâmina foliar 7,5-20 × 3,5-7,5 $\mathrm{cm}$, cartácea a coriácea, oblongo-elíptica, oblonga, às vezes lanceolada, ápice curto a longamente acuminado, obtuso ou agudo, base arredondada, sub-cordada ou cordada, margem plana, face adaxial glabra, nervura primária impressa, face abaxial tomentúlea a tomentosa, nervura primária proeminente, não alada, nervuras secundárias paralelas, proeminentes, 3-5 por cm de compr., nervura marginal presente. Inflorescências 8-23 cm compr., tirsos terminais e subterminais, com cíncinos 1-3-floros, opostos dísticos, eixo, pedúnculos, pedicelos, brácteas e bractéolas densamente ocráceo a ferrugíneos-tomentosos. Botões florais 1,3-2,3 × 0,3-1,3 cm, ápice agudo; sépalas externa e internamente ocráceas a esverdeadas, sépala calcarada 1,7-2,6 cm compr., ápice obtuso a arredondado, tomentosa, sépalas não calcaradas $1-1,4 \times 0,8-1 \mathrm{~cm}$, largo-ovadas a ovadas, ápice arredondado, tomentosas; cálcar 1,9-2,3 cm compr., desenvolvido, cilíndrico, incurvo, no botão floral fica escondido entre as sépalas não calcaradas, tomentoso; pétala 3,9-4,7 $\times 4,7-6 \mathrm{~cm}$, amarela, obcordada, ápice emarginado a obtuso, base atenuada, glabra, margem inteira, ondulada. Estame ca. 2,5 cm compr., filete ca. 1,3 cm compr., antera ca. 1,2 cm compr., basifixa, deltoide, reta a subcurvada, glabra. Ovário 4,4 × 4,2 $\mathrm{mm}$, seríceo; estilete 1,6-2 cm compr., cilíndrico, glabro. Cápsula 9-10,5 x 3,4-3,6 cm, oblonga, superfície lisa, não descamante, glabra.

Material selecionado: Datas, Distrito de Tombadouro, 11.XII.2011, fl., D.J.P. Gonçalves et al. 285 (UEC); Diamantina, próximo a Curvelo, 28.XI.2010, fl., D.J.P. Gonçalves et al. 92 (UEC); Estrada Mendanha, 16.XI.2011, fl., D.J.P. Gonçalves \& M.M.T. Cota 151 (UEC); Estrada Mendanha - Inhaí, 16.XI.2011, fl., D.J.P. Gonçalves \& M.M.T. Cota 161 (DIAM, UEC); Estrada Curralinho, 23.XI.2011, fl., D.J.P. Gonçalves 235 (DIA, UEC); Estrada Curralinho - Acaba Mundo, 24.XI.2011, fl., D.J.P. Gonçalves \& M.M.T. Cota 238 (DIAM, UEC); Estrada Conselheiro Mata - Rodeador, 12.XII.2011, fl., D.J.P. Gonçalves \& C.C. Mattioli 292 (UEC); Conselheiro Mata, 22.I.2012, fl., D.J.P. Gonçalves et al. 382 (DIAM, UEC); estrada entre Espinho e Rodeador, 24.I.2012, fr., D.J.P. Gonçalves et al. 407 (DIAM, UEC); 24.I.2012, fl., D.J.P. Gonçalves et al. 408 (DIAM, UEC); Gouveia, 28.II.1998, fl., J.P. Lemos Filho (BHCB 41138, SP 330120); 19.I.1969, fl., H.S. Irwin et al. 22292 (MO, NY, SPF, US); entre 


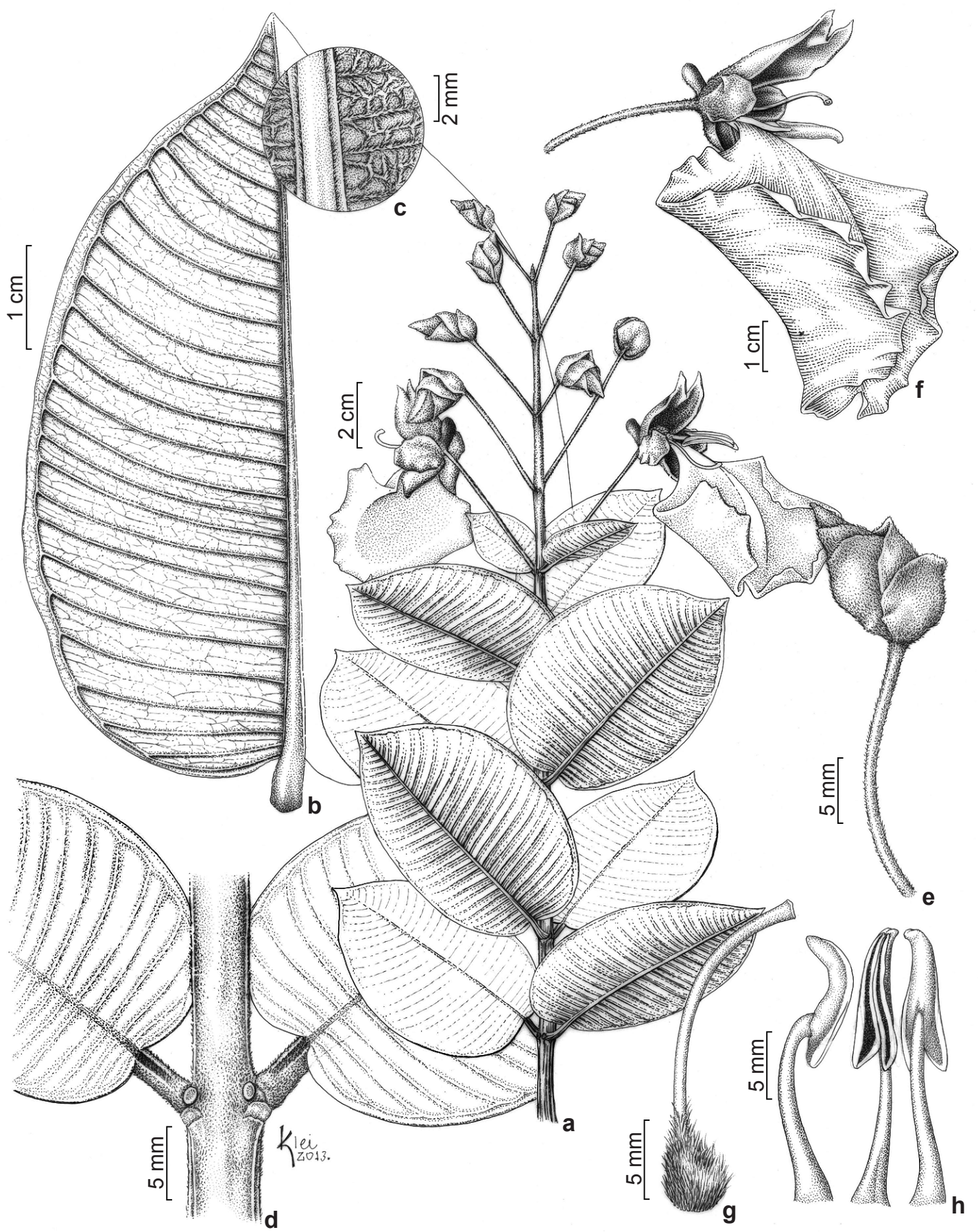

Figura 3 - a-h. Qualea elegans Taub. ex Benoist. - a. ramo florífero; b. face abaxial da folha; c. detalhe da nervura principal; d. detalhe do nó; e. botão floral; f. flor; g. Gineceu; h. estame em algumas vistas.

Figure 3 - a-h. Qualea elegans Taub. ex Benoist. - a. flowering branch; b. abaxial surface of leaf; c. midrib detail; d. node detail; e. flower bud; f. flower; g. gynoecium; h. stamen in some views. 


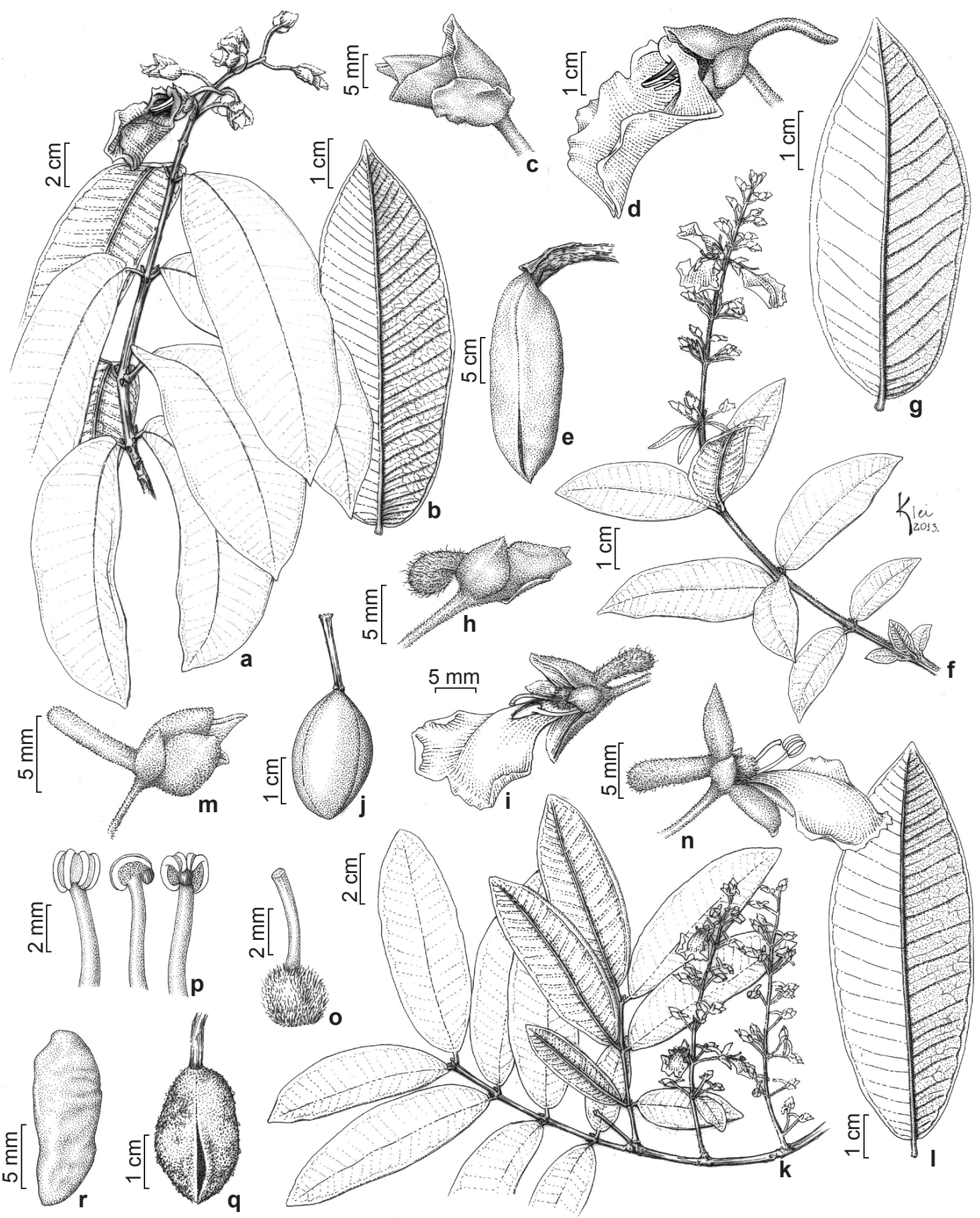

Figura 4 - a-e. Qualea grandiflora Mart. - a. ramo; b. face abaxial da folha; c. botão floral; d. flor; e. fruto. f-j. Qualea multiflora Mart. - f. ramo; g. face abaxial da folha; h. botão floral; i. flor; j. fruto. k-r. Qualea parviflora Mart. - k. ramo; 1. face abaxial da folha; $m$. botão floral; n. flor; o. gineceu; p. estame em algumas vistas; q. fruto; r. semente. Figure 4 - a-e. Qualea grandiflora Mart. - a. branch; b. abaxial surface of leaf; c. flower bud; d. flower; e. fruit; f-j. Qualea multiflora Mart. - f. branch; g. abaxial surface of leaf; h. flower bud; i. flower; j. fruit. k-r. Qualea parviflora Mart. - k. branch; 1. abaxial surface of leaf; m. flower bud; n. flower; o. gynoecium; p. stamen in some views; q. fruit; r. seed. 
Gouveia e Cuiabá, 10.XII.2011, fl. e fr., D.J.P. Gonçalves \& M.M.T. Cota 251 (UEC); São Gonçalo do Rio Preto, Parque Estadual do Rio Preto, estrada para o sanitário, 23.VI.2011, fr., D.J.P. Gonçalves et al. 100 (UEC); trilha para a Forquilha, 17.XI.2011, fl. e fr., D.J.P. Gonçalves et al. 172 (DIAM, UEC); Senador Modestino Gonçalves. Estação Ecológica Mata dos Ausentes, 26.I.2012, fl., D.J.P. Gonçalves et al. 437 (UEC).

Ocorre na Bolívia, Paraguai, Peru, Suriname e no Brasil ocorre nos estados AC, AM, BA, CE, GO, MA, MG, MS, MT, PA, PI, PR, RO, SP, TO e no DF (Gonçalves et al. 2013). Coletada com flores de novembro a janeiro e com frutos de novembro a janeiro e em junho. $\mathrm{Na}$ área de estudo ocorre entre 606 e 1109 m de altitude.

Dentre as espécies encontradas no PD, Qualea grandiflora é facilmente reconhecida por ser a única a apresentar ramos com casca descamante em placas. Qualea grandiflora se assemelha a Q. multiflora, da qual pode ser distinguida por apresentar inflorescências com um menor número de flores com pétalas amarelas (Fig. 4a), botões florais de 1,3-2,3 cm compr. e cálcar cilíndrico, com 1,9-2,3 cm compr. Qualea multiflora apresenta inflorescências com um maior número de flores e pétalas brancas com máculas magenta a amarelas com máculas púrpura (Fig. 4f), botões florais de 7-12 mm compr. e cálcar clavado, com 5-10 mm compr.

2.4. Qualea multiflora Mart., Nov. Gen. Sp. P1. 1: 134. 1826.

Fig. 4f-j

Ilustração: Shimizu \& Yamamoto (2012a), Gonçalves et al. (2013).

Nomes populares: uva-puva-do-campo (MG, $\mathrm{SP}$ ), pau-terra (MG, SP), louro-tinga (RJ), pauterra-do-campo, pau-de-tucano e cinzeiro (Stafleu 1953).

Árvores, 2-12 m alt. Ramos cilíndricos ou subquadrangulares, pubescentes a glabrescentes, casca dos ramos não descamante em placas. Folhas opostas cruzadas, raramente em verticilos 3-meros, alternas ou sub-alternas, pecíolo 4-7 $\mathrm{mm}$ compr., tomentoso; lâmina foliar 5-11 × 2,7-5,3 cm, cartácea a coriácea, elíptica, largo elíptica e às vezes lanceolada, ápice agudo, acuminado, abruptamente acuminado ou obtuso, base arredondada, subcordada ou cordada, margem plana, face adaxial tomentosa a glabrescente, nervura primária subimpressa ou impressa, face abaxial tomentosa, nervura primária proeminente, não alada, nervuras secundárias paralelas, proeminentes, 3-5 por cm de compr., nervura marginal presente. Inflorescências 8-22 cm compr., tirsos terminais e subterminais, com cíncinos 1-3-floros, opostos, verticilados ou sub-alternos, eixo, pedúnculo, pedicelos, brácteas e bractéolas ferrugíneos a ocráceo-tomentosos. Botões florais 7-12 × 4-8 mm, ápice agudo a acuminado; sépalas externa e internamente avermelhadas a esverdeadas, sépala calcarada 7-9 mm compr., pubescente, ápice arredondado a obtuso, sépalas não calcaradas 5-6× 4-5 mm, ovadas, pubescentes, ápice arredondado a obtuso; cálcar 0,5-1 cm compr., desenvolvido, fortemente incurvo, clavado, aparente no botão floral, tomentoso; pétala 1,6-3,5 × 2-2,6 cm, branca com máculas magenta ou amarela com máculas púrpura, obcordada, ápice emarginado, base atenuada, glabra, margem inteira, ondulada. Estame 1,1-1,9 cm compr., filete 8-14 mm compr., antera 3-5 mm compr., basifixa, deltoide, reta, glabra. Ovário 2-5 × $2 \mathrm{~mm}$, seríceo; estilete 6-14 mm compr., cilíndrico, glabro, seríceo na base. Cápsula $2-2,5 \times 1,3-1,9 \mathrm{~cm}$, oblonga a ovoide, superfície lisa, não descamante, glabra.

Material selecionado: Datas, Distrito de Tombadouro, 11.XII.2011, fl., D.J.P. Gonçalves et al. 284 (DIAM, UEC); Diamantina, $10 \mathrm{~km}$ de Mendanha, 10.IV.1995, R. Mello-Silva et al. 1053 (SP); Estrada Diamantina Curvelo, 23.X.2008, fl., P.O. Rosa et al. 1150 (HUFU); Estrada Diamantina - Mendanha, 10.XII.1992, fl., H.F. Leitão Filho et al. 27663 (HUFU); próximo a Curvelo, 28.XI.2010, fl., D.J.P. Gonçalves et al. 93 (UEC); Estrada Mendanha - Inhaí, 16.XI.2011, fl., D.J.P. Gonçalves \& M.M.T. Cota 164 (DIAM, UEC); Estrada Conselheiro Mata - Rodeador, 12.XII.2011, fl., D.J.P. Gonçalves \& C.C. Mattioli 293 (UEC); Estrada Rodeador - Santo Hipólito, 22.I.2012, fl., D.J.P. Gonçalves et al. 383 (DIAM, UEC); entre Espinho e Rodeador, 24.I.2012, fr., D.J.P. Gonçalves et al. 407 (UEC); Estrada Rodeador Conselheiro Mata, 24.I.2012, fl. e fr., D.J.P. Gonçalves et al. 409 (DIAM, UEC); primeira entrada de terra para Mendanha, 28.IV.2012, fr., D.J.P. Gonçalves et al. 503 (UEC); Gouveia. 28.II.1998, fl., J.P. Lemos Filho (BHCB 41139, SP 330119); entre Gouveia e Cuiabá, 10.XII.2011, fl., D.J.P Gonçalves \& M.M.T. Cota 254 (DIAM, UEC); entre Gouveia e Cuiabá, 10.XII.2011, fl., D.J.P Gonçalves \& M.M.T. Cota 256 (DIAM, UEC); Itamarandiba, Parque Estadual de Serra Negra, 26.I.2012, fl., D.J.P. Gonçalves et al. 436 (UEC); São Gonçalo do Rio Preto, Parque Estadual do Rio Preto, estrada para o sanitário, 23.VI.2011, fr., D.J.P. Gonçalves et al. 101 (DIAM, UEC); trilha para Forquilha, 17.XI.2011, fl., D.J.P. Gonçalves et al. 173 (DIAM, UEC); trilha entre Vau da Tropa e Lapa do Veado, 18.XI.2011, fl., D.J.P. Gonçalves et al. 188 (DIAM, UEC); Senador Modestino Gonçalves, estrada para Estação Ecológica Mata dos Ausentes, 25.I.2012, fl., D.J.P. Gonçalves et al. 419 (UEC); estrada entre a Estação Ecológica Mata dos Ausentes e a cidade, 25.I.2012, fl., D.J.P. Gonçalves et 
al. 420 (UEC); Serro, Estrada São Gonçalo do Rio das Pedras - Milho Verde, 21.II.2011, fl., D.J.P. Gonçalves \& M.M.T. Cota 229 (DIAM, UEC).

Ocorre na Bolívia, no Paraguai, no Peru e, no Brasil ocorre em AM, BA, ES, GO, MA, MG, MS, MT, PA, PI, PR, RJ, RO, RR, SP, TO e no DF (Gonçalves et al. 2013). Na área de estudo foi coletada com flores de outubro a janeiro, com frutos em janeiro, abril e junho, ocorrendo entre as altitudes 639 e $1203 \mathrm{~m}$. Ocorre principalmente em cerrado, mas também foi coletada em floresta ciliar, em campo rupestre e em áreas antropizadas.

Qualea multiflora pode ser reconhecida pelas flores com pétalas jovens brancas com máculas magenta e, quando velhas, amarelas com máculas púrpura. Dentre as espécies que ocorrem na área de estudo, assemelha-se a $Q$. grandiflora (vide comentários sob esta última) e a $Q$. parviflora. Além da cor da pétala, diferenciase de $Q$. parviflora por ter frutos com casca lisa, não descamante. Stafleu (1953) considerou duas subespécies, Q. multiflora subsp. multiflora, glabra, e Q. multiflora subsp. pubescens (Mart.) Stafleu, caracterizada pela presença de indumento na face abaxial das folhas, ramos jovens e gemas. No PD ocorrem as duas subespécies, mas como na área o indumento ocorre em gradiente, optamos por não considerar a divisão infraespecífica.

2.5. Qualea parviflora Mart., Nov. Gen. Sp. Pl. 1: 135. 1826

Fig. 4k-r

Ilustração: Yamamoto (2009), Shimizu \& Yamamoto (2012a), Gonçalves et al. (2013).

Nomes populares: pau-terra (MG), pauterra-com-folhas-miúdas, pau-terra-do-campo, pau-terra-miúda, pau-de-judeu (MA), craiba (CE).

Árvores, 1,5-4 m alt. Ramos cilíndricos ou subquadrangulares em partes jovens, pubescentes a glabrescentes, casca dos ramos não descamante em placas. Folhas opostas cruzadas, raramente em verticilos 3-meros; pecíolo 3-4,5 mm compr., pubescente a glabrescente; lâmina foliar 5-11 $\times$ 2,5-5 cm, cartácea, oblongo-elíptica, ápice arredondado, obtuso ou agudo, base arredondada, raramente sub-cordada, margem plana, face adaxial glabra ou tomentosa, nervura primária impressa, face abaxial glabra ou densamente tomentosa, nervura primária proeminente, não alada, nervuras secundárias paralelas, promínulas, ca. 5 por cm de compr., nervura marginal presente. Inflorescências 6-24 cm compr., tirsos terminais ou sinflorescências complexas de arquitetura predominantemente tirsoide, com cíncinos 1-4-floros, opostos cruzados ou alternos na porção distal do eixo da inflorescência, eixo, pedúnculo, pedicelos, brácteas e bractéolas pubescentes a canescentes. Botão floral 6-7 $\times$ 3,5-4,5 mm, ápice agudo; flores com cálice calcarado, sépalas externa e internamente cinéreas a violáceas, sépala calcarada 6-8 $\mathrm{mm}$ compr., ápice agudo, pubescente, sépalas não calcaradas 4-5 × 2-3 cm, ovadas, ápice agudo, tomentoso; cálcar 4,5-7,8 mm compr., desenvolvido, reto a incurvo, raramente recurvo, cilíndrico, aparente no botão floral, tomentoso; pétala $1-1,6 \times 0,7-1,8$ $\mathrm{cm}$, lilás, às vezes com linha central ou máculas alvas, obcordada, ápice emarginado a obtuso, base atenuada, glabra, margem inteira, ondulada. Estame 5-6,5 mm compr., filete 4,4-5,4 mm compr., antera 0,9-1,2 mm compr., dorsifixa, oblonga, curvada, glabra. Ovário 2-3 × 1,8-2, seríceo; estilete 3-4,5 $\mathrm{mm}$ compr., cilíndrico, glabro, seríceo na base. Cápsula 2-3 × 1,3-1,6 cm, ovoide, superfície lisa, descamante, glabra.

Material selecionado: Datas, Córrego Água Limpa, 18.III.1987, veg., G. Hatschbach et al. 51094 (NY); Diamantina, 15.XI.1937, fl., M. Barreto 9750 (F); 17.IX.1985, fl., C.A. Cid Ferreira et al. 6043 (F); estrada para Biri-Biri, 8.XII.1992, fl., H.F. Leitão Filho et al. 27454 (UEC); Estrada Diamantina - Mendanha, 10.XII.1992, fl., H.F. Leitão Filho et al. 27795 (UEC); Mineração Tejucana, X.1989, fr., L.V. Costa et al. 477 (UEC); Estrada Mendanha, 16.XI.2011, fl. e fr., D.J.P. Gonçalves \& M.M.T. Cota 155 (DIAM, UEC); Estrada Mendanha - Inhaí, 16.XI.2011, fl., D.J.P. Gonçalves \& M.M.T. Cota 166 (DIAM, UEC); 28.IV.2012, fr., D.J.P. Gonçalves et al. 508 (UEC); Curralinho - Acaba Mundo, 24.XI.2011, fl., D.J.P. Gonçalves \& M.M.T. Cota 237 (DIAM, UEC); Estrada Conselheiro Mata - Rodeador, 12.XII.2012, fl., D.J.P. Gonçalves \& C.C. Mattioli 294 (UEC); Estrada Ponte do Acaba Mundo - Chapada do Couto; 14.XII.2011, fl., D.J.P. Gonçalves et al. 322 (UEC); Estrada Diamantina - Milho Verde, 30.IV.2012, fr., D.J.P. Gonçalves et al. 533 (UEC); trilha para o Telésforo, 21.X.2007, fl., P.O. Rosa et al. 923 (HUFU, UEC); Gouveia, entre Gouveia e Cuiabá, 10.XII.2011, fl., D.J.P Gonçalves \& M.M.T. Cota 253 (DIAM, UEC); São Gonçalo do Rio Preto, Parque Estadual do Rio Preto, 18.XI.2005, fl., F.N. Costa \& L.G. Lessa 928 (ESA); estrada para o sanitário, 23.VI.2011, fr., D.J.P. Gonçalves et al. 104 (DIAM, UEC); 17.XI.2011, fl., D.J.P. Gonçalves et al. 171 (DIAM, UEC); trilha para Forquilha, 17.XI.2011, fl., D.J.P. Gonçalves et al. 174 (DIAM, UEC); heliporto em direção ao Rio Preto, 18.XI.2011, fl., D.J.P. Gonçalves et al. 183 (DIAM, UEC); trilha entre Vau da Tropa e Lapa do Veado, 18.XI.2011, fl., D.J.P. Gonçalves et al. 189 (DIAM, UEC); 1.V.2012, fr., D.J.P. Gonçalves et al. 542 (UEC). 
Qualea parviflora é uma espécie amplamente distribuída em áreas de cerrado s.s. e outras formações savânicas adjacentes, tendo registros na Bolívia, Paraguai e no Brasil, onde ocorre no AM, BA, CE, GO, MA, MG, MS, MT, PA, PI, RO, SP, TO e no DF (Gonçalves et al. 2013). No PD foi coletada em cerrado e capão de mata e raramente em campos e cerrados rupestres. Encontrada com flores de setembro a dezembro e frutos em fevereiro, de abril a junho e em outubro. $\mathrm{Na}$ área de estudo ocorre entre 710 e $1053 \mathrm{~m}$ de altitude.

Qualea parviflora pode ser reconhecida pelas pétalas lilases às vezes com máculas alvas, pela cápsula de superfície descamante e pelas inflorescências canescentes, enquanto as outras espécies de Qualea que ocorrem no PD apresentam cápsula com superfície não descamante e inflorescências ferrugíneas a ocráceas (vide comentários sobre Q. multiflora).

\section{Salvertia A.St.-Hil.}

Árvores ou arbustos; ramos cilíndricos; casca não descamante em placas. Folhas em verticilos 7-9-meros, não dispostas em râmulos filomórficos, catáfilos ausentes, estípulas decíduas e sem glândulas associadas; pecioladas. Inflorescências tirsos terminais, compostos por cíncinos verticilados na região proximal e alternos na região distal da inflorescência; brácteas e bractéolas decíduas; botões florais retos, oblongos, ápice agudo a arredondado; flores com cálice calcarado, cálcar desenvolvido, incurvo, cilíndrico, aparente no botão floral, indumentado; pétalas 5, subiguais, alvas, glabras, margem inteira, ondulada, persistentes na antese. Estame no plano de simetria da flor, persistente na antese; estaminódios 2, antera deltoide, basifixa. Ovário com 2 óvulos por lóculo, piramidal, estilete clavado, curvado, estigma lateral, ligulado. Cápsula oblonga; exocarpo lenhoso, não quebradiço; columela central ausente; região central das valvas fundidas no terço basal, após a deiscência. Sementes 1 por lóculo, unilateralmente aladas.

3.1. Salvertia convallariodora A. St.-Hil., Mém. Mus. Hist. Nat. 6: 259. $1820 . \quad$ Fig. 5a-g

Ilustração: Shimizu \& Yamamoto (2012a), Gonçalves et al. (2013).

Nome popular: bananeira-do-campo, colherde-vaqueiro, moliana (MG), folha-larga (MA, MT, PI), pau-de-arara (AM) (Stafleu 1948; BFG 2015).

Árvores, 2-3,5(-5) m alt. Ramos cilíndricos, pubescentes, casca não descamante em placas, glândulas ausentes na região dos nós, associadas às estípulas. Folhas em verticilos 7-9-meros, pecíolo ca. $2 \mathrm{~cm}$ compr., tomentoso a glabrescente; lâmina 20-24 × 10,5-18,5 cm, coriácea, largo-obovada a obovada, ápice emarginado, base decurrente ou cuneada, margem plana, face adaxial glabra, nervura primária impressa, face abaxial glabra, nervura primária proeminente, não alada, nervuras secundárias proeminentes, venação broquidódroma, nervura marginal ausente. Inflorescências ca. $50 \mathrm{~cm}$ compr., tirsos terminais, com cíncinos 1-4-floros, em verticilos 6-8-meros na região proximal, tendendo a subalterno ou alterno na região distal, eixo, pedúnculos, brácteas e bractéolas ferrugíneopubescentes. Botões florais 2-2,5 × 0,5-1 cm, ápice agudo a arredondado; flores com cálice calcarado, sépala calcarada 1,8-2 cm compr., ápice agudo a arredondado, pubescente, sépalas laterais 1,8-2 $\times$ $0,5-0,7 \mathrm{~cm}$, oblongas, ápice agudo a arredondado, pubescente; cálcar 5-6,8 $\mathrm{mm}$, desenvolvido, incurvo, cilíndrico, pubescente; pétalas 1,9-2,1 $\times$ $1,2-1,4 \mathrm{~cm}$, alvas, oblongas, ápice arredondado a obtuso, base truncada, glabras, margem inteira, plana. Estame ca. $1,9 \mathrm{~cm}$ compr., filete $0,3 \mathrm{~cm}$ compr., antera 1,9 cm compr., glabra. Ovário ca. $3 \times 3 \mathrm{~mm}$, tomentoso; estilete ca. 1,7 cm compr., clavado, estigma lateral, ligulado, glabro. Cápsula 3-4,5 × 1,5-2 cm, oblonga, superfície verrucosa, não descamante, pubérula.

Material examinado: Diamantina, Estrada Conselheiro Mata - Rodeador, 12.XII.2011, fr., D.J.P. Gonçalves \& C.C. Mattioli 291 (UEC).

Material adicional examinado: Curvelo, 2.V.2012, fl., D.J.P. Gonçalves et al. 547 (UEC).

Salvertia convallariodora ocorre em ambientes savânicos na Bolívia, Suriname e em cerrado s.s. do Brasil, nos seguintes estados: AM, AP, BA, GO, MA, MG, MS, MT, PA, PI, RO, SP, TO e DF (Shimizu \& Yamamoto 2012a). Coletada com flores em abril, maio e dezembro e com frutos em dezembro. No PD foi encontrada próxima a Rodeador (município de Monjolos) em uma área de menor elevação (724 m de altitude), onde há predomínio de cerrado s.s. Pode ser facilmente distinguida das outras Vochysiaceae que ocorrem no PD por apresentar folhas com pelo menos $20 \mathrm{~cm}$ de comprimento, dispostas em verticilos 7-9-meros, e flores vistosas com cinco pétalas brancas.

\section{Vochysia Aubl.}

Árvores de grande porte a pequenos arbustos ramificados ou pouco ramificados; eretos ou decumbentes; ramos cilíndricos ou quadrangulares, estes em geral quando jovens; 


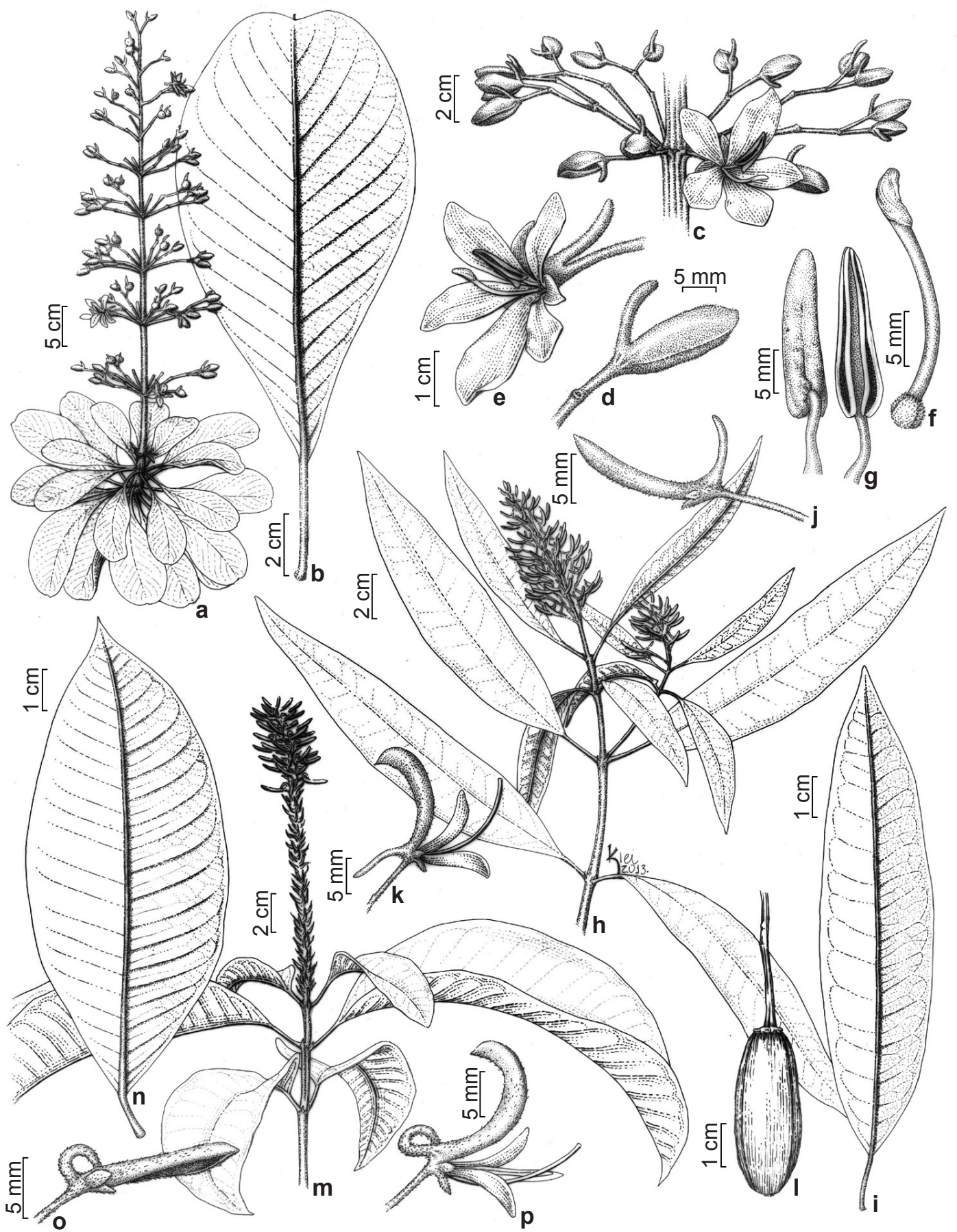

Figura 5 - a-g. Salvertia convallariodora A.St.-Hil. - a. ramo; b. face abaxial da folha; c. detalhe de um nó da inflorescência; d. botão floral; e. flor; f. gineceu; g. estame em duas vistas. h-1. Vochysia acuminata Bong. - h. ramo; i. face abaxial da folha; j. botão floral; k. flor; 1. fruto. m-p. Vochysia dasyantha Warm. - m. ramo; n. face abaxial da folha; o. botão floral; p. flor.

Figure 5 - a-g. Salvertia convallariodora A.St.-Hil. - a. branch; b. abaxial surface of leaf; c. detail of an inflorescence node; d. flower bud; e. flower; f. gynoecium; g. stamen in two views. h-l. Vochysia acuminata Bong. - h. branch; i. abaxial surface of leaf; j. flower bud; k. flower; 1. fruit. m-p. Vochysia dasyantha Warm. - m. branch; n. abaxial surface of leaf; o. flower bud; p. flower. 
casca descamante em placas ou não. Folhas opostas cruzadas ou em verticilos 3-5-meros, não dispostas em râmulos filomórficos, catáfilos ausentes, estípulas decíduas ou persistentes, sem glândulas associadas; pecioladas a subsésseis. Inflorescências tirsos terminais ou subterminais, compostos por cíncinos alternos espiralados a subespiralados ao longo do eixo da inflorescência; brácteas decíduas, raramente persistentes; botões florais retos ou incurvos, oblongos, ápice agudo ou arredondado, apiculado ou não; flores com cálice calcarado, cálcar fortemente incurvo, reto, recurvo a fortemente recurvo, cilíndrico ou cônico, aparente no botão floral, glabro ou indumentado; pétalas 3 , desiguais, pétala central maior que as laterais e oposta ao lobo calcarado do cálice, amarelas, decíduas após a antese. Estame no plano de simetria da flor, decíduo no início da antese; estaminódios 2; antera oblonga, basifixa. Ovário com 2 óvulos por lóculo, piramidal ou subgloboso, estilete clavado, curvado, estigma terminal ou subterminal, não ligulado. Cápsula oblonga, oblongo-ovoide ou ovoide, com exocarpo lenhoso, não quebradiço; columela central ausente; região central das valvas geralmente fundidas ou um pouco afastadas apenas na região apical, após a deiscência. Sementes 1 por lóculo, unilateralmente aladas.

Vochysia é o maior gênero da família compreendendo 142 espécies distribuídas na região Neotropical, dentre as quais 86 espécies possuem registro no Brasil. Stafleu (1948) classificou o gênero em três seções e 8 subseções. No PD foram inventariadas 13 espécies incluídas em $V$. sect. Vochysiella subsect. Decorticantes (Warm.) Stafleu (4 spp.) e $V$. sect. Ciliantha subsect. Lutescentes (Warm.) Stafleu (6 spp.), V. subsect. Discolores Stafleu (1 sp.) e $V$. subsect. Ferrugineae (Warm.) Stafleu (2 spp.). Estas podem ser distinguidas das demais espécies de Vochysiaceae ocorrentes no PD pela combinação dos seguintes caracteres: folhas não dispostas em râmulos filomórficos, ausência de glândulas na região das estípulas, corola com três pétalas amarelas e estame cedo decíduo, flores dispostas em inflorescências vistosas amareloesverdeadas em botão e amarelas na antese. Além das espécies de Vochysiaceae usualmente encontradas no Cerrado, foram encontradas uma espécie ainda não descrita e duas espécies que até recentemente só haviam sido registradas em regiões situadas a leste da Cadeia do Espinhaço, onde há predomínio de Floresta Atlântica.

\section{Chave para identificação das espécies de Vochysia no Planalto de Diamantina}

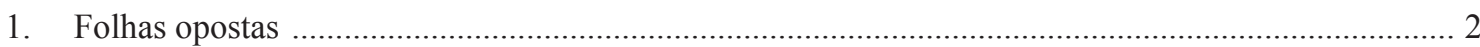

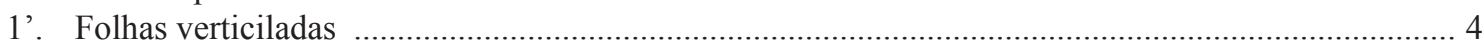

2. Nervuras secundárias proeminentes na face abaxial das folhas; brácteas persistentes; cálcar fortemente incurvo no botão e na flor aberta, enrolando-se e tocando a região dorsal da sépala calcarada 2. Vochysia dasyantha

2'. Nervuras secundárias planas ou promínulas na face abaxial das folhas; brácteas decíduas; cálcar reto a levemente incurvo (não toca a região dorsal da sépala) ou fortemente recurvo (podendo tocar o pedicelo) no botão floral ou na flor aberta

3. Folhas lanceoladas, às vezes oblongo-lanceoladas ou oblongo-elípticas, ápice gradualmente acuminado; cálcar reto a levemente incurvo no botão floral ............. 1. Vochysia acuminata

3'. Folhas oblongas, elípticas ou obovadas, ápice emarginado; cálcar reto a recurvo no botão floral 5. Vochysia emarginata

4. Casca dos ramos descamante em placas; ovário indumentado ................................... 5

4'. Casca dos ramos não descamante em placas; ovário glabro ..................................... 8

5. Pecíolo 15-30 mm compr.; folhas conduplicadas; inflorescência $27-48 \mathrm{~cm}$ compr.

10. Vochysia rufa

5'. Pecíolo 1-13 mm compr.; folhas planas; inflorescência (5)10-26 cm compr. .... 6

6. Folhas pecioladas, pecíolo $10-13 \mathrm{~mm}$ compr. ............ 6. Vochysia gardneri

6'. Folhas curto-pecioladas ou subsséseis, pecíolo 1-6 mm compr. .................. 7

7. Arbusto decumbente; folhas não glauco-pruinosas, margem revoluta; inflorescências ca. $8 \mathrm{~cm}$ compr. ................................... 13. Vochysia sp.

7'. Arbusto ereto ou árvore; folhas glauco-pruinosas, margem plana; inflorescências (5)10-22 cm compr. 4. Vochysia elliptica 
8. Subarbustos ou arbustos eretos; folhas em verticilos 3-meros, raro 4-5-meros no mesmo indivíduo; subsésseis ou pecioladas, pecíolos até ca. $2 \mathrm{~mm}$ compr.

8'. Árvores de pequeno a grande porte; folhas em verticilos 4-meros; pecioladas, pecíolos maiores que $3 \mathrm{~mm}$ compr.

9. Folhas obovadas a elípticas, base cuneda inflorescência 11-12 cm compr., esparsamente pubescente

8. Vochysia pygmaea

9'. Folhas orbiculares, base cordada; inflorescência 14-15 cm compr., glabra, com tricomas apenas na região das axilas 9. Vochysia rotundifolia

10. Árvores de grande porte; pecíolo glabro; cálcar fortemente incurvo no botão floral

7. Vochysia oppugnata

10'. Árvores de pequeno a médio porte; pecíolo com indumento pubescente ou pubérulo, às vezes glabrescente; cálcar recurvo, reto ou incurvo no botão floral ... 11

11. Folhas cartáceas, margem foliar revoluta apenas no terço proximal; cápsula 1,7-1,8 cm compr. 12. Vochysia tucanorum

11'. Folhas coriáceas, margem revoluta; cápsula 2,5-2,8 cm compr. 12

12. Face abaxial das folhas glabra ou gríseo-tomentúlea a glabrescente, não conferindo aspecto discolor à folha 11. Vochysia thyrsoidea

12'. Face abaxial das folhas densamente ferrugíneo-tomentosa ..... 3. Vochysia discolor

4.1. Vochysia acuminata Bong., Mém. Acad. Imp. Sci. Saint-Pétersbourg, Sér. 6, Sci. Math., Seconde Pt. Sci. Nat. 3(2): 5, t. 3. $1840 . \quad$ Fig. 5h-1 Ilustração: Yamamoto (2009), Shimizu \& Yamamoto (2012a).

Nome popular: canela-ruiva (Stafleu 1948).

Árvores de pequeno a médio porte, 3-8 m alt. Ramos cilíndricos, quadrangulares quando jovens, casca não descamante em placas. Folhas opostas cruzadas, pecioladas, pecíolo 13-26 mm compr., pubescente; lâmina foliar 6-17,5 × 1,5-4,5 cm, cartácea, plana, não glauca, lanceolada, às vezes oblongo-lanceolada ou oblongo-elíptica, ápice gradualmente acuminado, base cuneada, margem plana, face adaxial glabra, nervura primária impressa, glabra, nervuras secundárias e terciárias planas, face abaxial gríseo-pubérula a glabrescente, nervura primária proeminente, nervuras secundárias e terciárias planas a promínulas. Inflorescências 4-10 cm compr., tirsos terminais ou terminais e subterminais, com cíncinos 2-3-floros, eixo, pedúnculos, pedicelos, brácteas e bractéolas tomentosos; brácteas decíduas. Botões florais 10-18 $\times 2 \mathrm{~mm}$, retos a levemente incurvos, ápice agudo ou acuminado, apiculado; sépala calcarada 5-6,8 mm compr., tomentosa, ápice agudo, sépalas não calcaradas $1,5-2,8 \times 1,7-2 \mathrm{~mm}$, tomentosas, deltoides, ápice agudo; cálcar 4-8 mm compr., cilíndrico, reto a levemente incurvo no botão floral, tornando-se recurvo e paralelo ao pedicelo na flor aberta, tomentoso; pétala central $10-21 \times 3-5 \mathrm{~mm}$, pubescente, com adensamento na região da nervura primária, amarela, oblonga, ápice arredondado, base truncada; pétalas laterais $0,4-1 \times 0,1-0,4$ $\mathrm{cm}$, glabras, amarelas, oblongas, ápice agudo a arredondado, base truncada. Estame 1,2-1,4 cm compr., filete 3-4 mm compr., antera $9-10 \mathrm{~mm}$ compr., tomentosa. Ovário 1,1-1,3 × 1,5 mm, piramidal, glabro; estilete $9-21 \mathrm{~mm}$ compr., glabro. Cápsula 1,5-1,9 × 0,7 cm, oblonga, superfície verrucosa, glabra.

Material selecionado: Datas, depois do trevo, 11.XII.2011, fl. e fr., D.J.P. Gonçalves et al. 279 (DIAM, UEC); Diamantina, road to Mendanha, 26.I.1969, fr., H.S. Irwin et al. 22637 (NY); Estrada Diamantina Biri-Biri, 31.X.1981, f1., A.M. Giulietti et al. CFCR 2536 (UEC); Rodovia Diamantina - São Gonçalo do Rio Preto, 24.XI.2011, fl., D.J.P. Gonçalves \& M.M.T. Cota 244 (DIAM, UEC); Parque Nacional das Sempre Vivas, 16.XII.2012, fl. e fr., D.J.P. Gonçalves et al. 336 (UEC); Couto Magalhães, 22.XI.1964, A.P. Duarte 8544 (UEC); 25.V.1955, fl., E. Pereira 1503 (UEC); Estrada Telésforo, 21.X.2007, fl., P.O. Rosa et al. 960 (HUFU, UEC); Gouveia, Córrego do Tigre, 5.IX.1971, fl., G. Hatschbach 27028 (UEC, US); São Gonçalo do Rio Preto, Parque Estadual do Rio Preto, do alojamento ao Ribeirão das Éguas, 18.XI.1999, fl., J.A. Lombardi 3490 (ESA); 20.VIII.2005, fl., E.B. Foresto et al. 56 (NY); 31.X.2005, fl., E.B. Foresto et al. 105 (UEC); heliporto, 18.XI.2011, fl. e fr., D.J.P. Gonçalves et al. 182 (DIAM, UEC); margem do Rio Preto, 18.XI.2011, fl., D.J.P. Gonçalves et al. 190 (UEC); próximo a Cachoeira do Crioulo, 19.XI.2011, fr., D.J.P. Gonçalves et al. 213 (DIAM, UEC); próximo a Cachoeira do Crioulo, 19.XI.2011, fl., D.J.P. Gonçalves et al. 215 (DIAM, UEC); 1.V.2012, fl., D.J.P. Gonçalves et al. 545 (UEC). 
Vochysia acuminata ocorre apenas na Cadeia do Espinhaço (BA e MG), nas margens de formações florestais associadas a corpos d'água. No Planalto de Diamantina é encontrada em florestas de galeria ou em áreas abertas às margens de rios, em elevações entre 750 e $1250 \mathrm{~m}$ altitude. Coletada com flor em maio, agosto e de setembro a dezembro e com frutos nos meses de novembro a janeiro. Difere das demais espécies de Vochysia que ocorrem no PD por apresentar duas características em conjunto: filotaxia oposta e ápice do botão floral agudo ou acuminado. Podem ser encontradas outras quatro espécies em formações florestais no $\mathrm{PD}, V$. emarginata, $V$. dasyantha, $V$. oppugnata $\mathrm{e}$ $V$. tucanorum. Vochysia acuminata e $V$. dasyantha são as únicas com folhas opostas de base e ápice semelhantes (estreitos), e podem ser diferenciadas pelas nervuras secundárias na face abaxial das folhas planas a promínulas em $V$. acuminata e proeminentes em $V$. dasyantha. As outras três espécies florestais, V. emarginata, $V$. oppugnata e $V$. tucanorum, possuem base e ápice das folhas desiguais (base estreita e ápice alargado), com base cuneada e frequentemente decurrente e ápice de formas variadas, geralmente retuso ou emarginado.

\subsection{Vochysia dasyantha Warm. in Martius \&} Eichler, Fl. bras. 13(2): 95. $1875 . \quad$ Fig. 5m-p Ilustração: Vianna (1980).

Nomes populares: murici-branco, murici-rosa. Árvores de médio a grande porte, $13-15 \mathrm{~m}$ alt. Ramos quadrangulares, casca não descamante em placas. Folhas opostas cruzadas, pecioladas, pecíolo 12-16 mm compr., pubescente; lâmina 12,4-23 × 5-7,5 cm, cartácea, plana, não glauca, oblonga a elíptica, ápice acuminado, base cuneada ou atenuada, margem plana, face adaxial glabrescente, nervura primária impressa, glabra, nervuras secundárias e terciárias planas, face abaxial gríseo-tomentosa, nervura primária e secundárias proeminentes, terciárias promínulas. Inflorescências $7-16 \mathrm{~cm}$ compr., tirsos terminais, com cíncinos 2-3-floros, eixo, pedúnculos, pedicelos, brácteas e bractéolas tomentosos; brácteas persistentes. Botões florais 13-17 × 1-3 $\mathrm{mm}$, retos, ápice agudo; sépala calcarada 5-6,8 mm compr., tomentosa a glabrescente, ápice agudo, sépalas não calcaradas ca. $2 \times 2 \mathrm{~mm}$, tomentosas, deltoides, ápice agudo; cálcar 8-9 $\mathrm{mm}$ compr., cilíndrico, fortemente incurvo no botão e na flor aberta, enrola-se e toca a região dorsal da sépala calcarada, tomentoso; pétala central 1,4-1,5 $\times$ $0,3-0,4 \mathrm{~cm}$, amarela, oblonga, ápice arredondado, base truncada, tomentúlea na face adaxial e tomentosa na face abaxial; pétalas laterais $0,9-1,1$ $\times 0,2 \mathrm{~cm}$, amarelas, oblongas, ápice agudo a arredondado, base truncada, tomentúleas na face abaxial. Estame 1,2-1,3 cm compr., tomentúleo, com adensamento na região do ápice do filete $\mathrm{e}$ da antera, filete ca. $0,3 \mathrm{~cm}$ compr., antera $0,9-1$ $\mathrm{cm}$ compr.. Ovário 1,5-1,9 × 1,5 mm, piramidal, glabro; estilete 1,2-1,4 cm compr., glabro. Cápsula imatura ca. $2,5 \times 1 \mathrm{~cm}$, superfície minutamente verruculosa, glabra (Vianna 2002).

Material examinado: Serro, 21.XI.2011, fl., D.J.P. Gonçalves \& M.M.T. Cota 232 (DIAM, UEC).

Material adicional examinado: Descoberto, 5.X.2001, fl., A.V. Lopes \& V.R. Scalon 26 (MBM, SPF, UEC).

Ocorre no Espírito Santo, em Minas Gerais e no Rio de Janeiro, sendo predominantemente coletada em comunidades florestais de beira de rios da encosta Atlântica (Vianna 2002). No PD foi encontrada em floresta de galeria, sendo este o seu atual limite norte de distribuição geográfica e o ponto mais elevado de ocorrência da espécie, 1027 $m$ de altitude. Coletada com flores em novembro. Dentre as espécies do gênero que ocorrem no PD, Vochysia dasyantha pode ser reconhecida pela presença de nervuras secundárias proeminentes na face abaxial das folhas e inflorescências com brácteas persistentes.

4.3. Vochysia discolor Warm. in Mart. \& Eichler, Fl. bras. 13(2): 81. $1875 . \quad$ Fig. 6a-e Nome popular: cinzeiro.

Árvores de pequeno a médio porte, 0,5-10 $\mathrm{m}$ alt. Ramos cilíndricos, casca não descamante em placas. Folhas em verticilos 4-meros, pecioladas, pecíolo 10-15 mm compr., pubescente a glabrescente; lâmina foliar 8-13 × 2,5-4 cm, coriácea, plana, não glauca, oblonga a ligeiramente obovada, ápice emarginado, base cuneada, raro atenuada ou arredondada, margem revoluta, face adaxial glabra ou tomentúlea a glabrescente, nervura primária impressa, gríseo-tomentosa, nervuras secundárias e terciárias planas, face abaxial densamente ferrugíneo-tomentosa, nervura primária proeminente, nervuras secundárias e terciárias planas (inconspícuas). Inflorescências 10-35 cm compr., tirsos terminais e subterminais, com cíncinos 2-3-floros, eixo, pedúnculos e brácteas pubescentes a glabrescentes, pedicelos e bractéolas glabros; brácteas decíduas. Botões florais $1,7-2,1 \times 0,2-0,45 \mathrm{~cm}$, incurvos, ápice arredondado, às vezes agudo; sépala calcarada $1,8-2,25 \mathrm{~cm}$ compr., glabra, ápice truncado, 
sépalas não calcaradas 1,5-3 × 1,5-2 mm, glabras, deltoides, ápice agudo, ciliadas na margem; cálcar 0,7-1 cm compr., glabro, cilíndrico, no botão floral e na flor reto a recurvo, podendo ser paralelo ou tocar o pedicelo, glabro; pétala central 1,6-2,3 $\times$ $0,3 \mathrm{~cm}$, glabra, amarela, oblonga a espatulada, ápice arredondado, base truncada; pétalas laterais 1,1-1,6 $\times 0,3-0,4 \mathrm{~cm}$, glabras, amarelas, oblongas, ápice arredondado, base truncada. Estame 1,8-2,2 cm compr., tomentoso na porção interna, filete $0,4-0,6$ cm compr., antera 1,4-1,6 cm compr. Ovário ca. $2 \times$ $2 \mathrm{~mm}$, piramidal, glabro; estilete 1,3-1,8 cm compr., glabro. Cápsula ca. 2,8 $\times 1,6 \mathrm{~cm}$, oblongo-ovoide a ovoide, superfície verrucosa, glabra.

Material selecionado: Datas, entre o trevo de Datas, 11.XII.2011, fl., D.J.P. Gonçalves et al. 282 (DIAM, UEC); entre Várzea do Basto e a rodovia para Diamantina, 11.XII.2011, fl., D.J.P. Gonçalves et al. 290 (DIAM, UEC); Diamantina, Estrada Biri-Biri, 6.VII.1996, fr., V.C. Souza et al. 11894 (ESA); 26.XI.2004, fl., F. Almeda et al. 8950 (UEC); $2 \mathrm{~km}$ de Diamantina em direção à Mendanha, 6.VII.1996, fr., V.C. Souza et al. 11844 (ESA); Estrada Diamantina - Mendanha, 08.I.2003, fl., A.O. Araújo et al. 329 (ESA); estrada para Curralinho, 2.XII.1976, fl., G.J. Shepherd et al. 3974 (UEC); BiriBiri, 28.XI.1985, fl., G. Hatschbach \& F.J. Zelma 50278 (MO, US); Estrada Diamantina - Biri-Biri, 25.IX.2008, fl., R. Romero et al. 8188 (UEC); 2.XII.1981, fl., N. Hensold et al. CFCR 2655 (UEC); 29.X.1981, fl. e fr., A.M. Giulietti et al. CFCR 2215 (UEC); road to Mendanha, 27.I.1969, fr., H.S. Irwin et al. 22695 (MO, NY, US); Serra dos Cristais, 06.XI.1937, fl., H.L. Mello Barreto 9568 (F); Guinda, 5.XI.1937, fl., H.L. Mello Barreto 9484 (F); Mendanha, 25.I.2002, fl. e fr., A.R. Barbosa et al. 290 (UEC); Estrada Gouveia, 28.XI.2010, fl., D.J.P. Gonçalves et al. 98 (UEC); Estrada Sopa - São João da Chapada, 27.VI.2011, fr., D.J.P. Gonçalves et al. 113 (DIAM, UEC); 15.XI.2011, fl., D.J.P. Gonçalves \& M.M.T. Cota 148 (DIAM, UEC); estrada entre Guinda e Sopa, 15.XI.2011, f1., D.J.P. Gonçalves \& M.M.T. Cota 141 (DIAM, UEC); estrada pouco depois de Sopa, 15.XI.2011, fl., D.J.P. Gonçalves \& M.M.T. Cota 144 (DIAM, UEC); Estrada Mendanha, 16.XI.2011, fl., D.J.P. Gonçalves \& M.M.T. Cota 152 (DIAM, UEC); Estrada Mendanha - Inhaí, 16.XI.2011, fl., D.J.P. Gonçalves \& M.M.T. Cota 158 (DIAM, UEC); Estrada Diamantina São Gonçalo do Rio das Pedras, 21.XI.2011, fl., D.J.P. Gonçalves \& M.M.T. Cota 222 (UEC); no Cruzeiro da Cidade, 24.XI.2011, fl., D.J.P. Gonçalves \& M.M.T. Cota 243 (UEC); Estrada Conselheiro Mata - Diamantina, 12.XII.2011, f1., D.J.P. Gonçalves \& C.C. Mattioli 298 (UEC); Estrada Barão de Guaicuí, 13.XII.2011, fl., D.J.P. Gonçalves et al. 308 (UEC); Estrada Curralinho - Acaba Mundo, 14.XII.2011, fl. e fr., D.J.P. Gonçalves et al. 320 (UEC); Estrada Ponte do Acaba Mundo - Chapada do Couto, 14.XII.2011, fl., D.J.P. Gonçalves et al. 324
(UEC); Parque Nacional das Sempre Vivas, 15.XII.2012, fl., D.J.P. Gonçalves et al. 333 (UEC); 16.XII.2012, fl., D.J.P. Gonçalves et al. 342 (UEC); Estrada Diamantina - Serro, 18.XII.2011, fl. e fr., D.J.P. Gonçalves et al. 374 (UEC); estrada entre Mendanha e Inhaí, 28.IV.2012, fr., D.J.P. Gonçalves et al. 515 (UEC). Estrada Diamantina - Milho Verde, 30.IV.2012, fr., D.J.P. Gonçalves et al. 530 (UEC); Gouveia, estrada entre Gouveia - Curvelo, 17.VI.2005, fr., M.D. Moraes 752 (UEC); road to Diamantina. 4.II.1972, fl., W.R. Anderson et al. 35389 (NY); estrada entre Gouveia e o trevão, 10.XII.2011, f1., D.J.P. Gonçalves et al. 266 (UEC); estrada entre Chapadinha e Barão de Guaicuí, 13.XII.2011, fl., D.J.P. Gonçalves et al. 302 (UEC); 13.XII.2011, fl., D.J.P. Gonçalves et al. 304 (UEC); Estrada Barão de Guaicuí, 13.XII.2011, fl. e fr., D.J.P. Gonçalves et al. 314 (UEC); Presidente Kubitschek, estrada entre Presidente Kubitschek - Gouveia, 9.I.1987, fl., T.S.M. Grandi et al. 8120 (UEC); Rio Vermelho, Pedra Menina, 1.VIII.1985, fr., J.R. Pirani et al. CFCR 7881 (UEC); São Gonçalo do Rio Preto, Parque Estadual do Rio Preto, trilha para a cascata do Córrego das Éguas, 19.X.2000, fl., J.A. Lombardi 4168 (ESA); 24.VI.2011, fr., D.J.P. Gonçalves et al. 107 (DIAM, UEC); próximo à Casa dos Vigilantes, 17.XI.2011, fl., D.J.P. Gonçalves et al. 170 (DIAM, UEC); próximo ao Vau da Tropa, 18.XI.2011, fl., D.J.P. Gonçalves et al. 185 (DIAM, UEC); trilha para Cachoeira do Crioulo, 19.XI.2011, fl., D.J.P. Gonçalves et al. 204 (DIAM, UEC); Senador Modestino Gonçalves, Serra do Ambrósio, 28.II.2011, D.J.P. Gonçalves et al. 480 (UEC); Serro, estrada próximo à entrada para Presidente Kubitschek, 11.XII.2011, fl., D.J.P. Gonçalves et al. 273 (DIAM, UEC).

Vochysia discolor é endêmica da porção mineira da Cadeia do Espinhaço, ocorrendo principalmente na região do $\mathrm{PD}$ e menos comumente na Serra do Cipó e na Serra do Cabral. No PD foi encontrada em campos rupestres e ocasionalmente em cerrados rupestres e cerrado s.s., entre 700 e $1300 \mathrm{~m}$ de altitude. Coletada com flores de outubro a janeiro e com frutos em janeiro, fevereiro, abril, de junho a agosto e em outubro. Dentre as espécies de Vochysia, pode ser confundida com $V$. thyrsoidea, da qual se diferencia por apresentar a face abaxial das folhas densamente ferrugíneo-tomentosas, o que deixa a folha discolor. Vochysia thyrsoidea tem a face abaxial das folhas geralmente glabras e, quando há indumento, os tricomas são gríseos e não conferem aspecto discolor à folha.

4.4. Vochysia elliptica Mart., Nov. Gen. Sp. Pl. 1: 141, t. 84. 1826.

Fig. 6f-j

Ilustração: Yamamoto (2009), Shimizu \& Yamamoto (2012a), Gonçalves et al. (2013). Nome popular: pau-doce (Stafleu 1948). Arbustos eretos e ramificados ou árvores de 


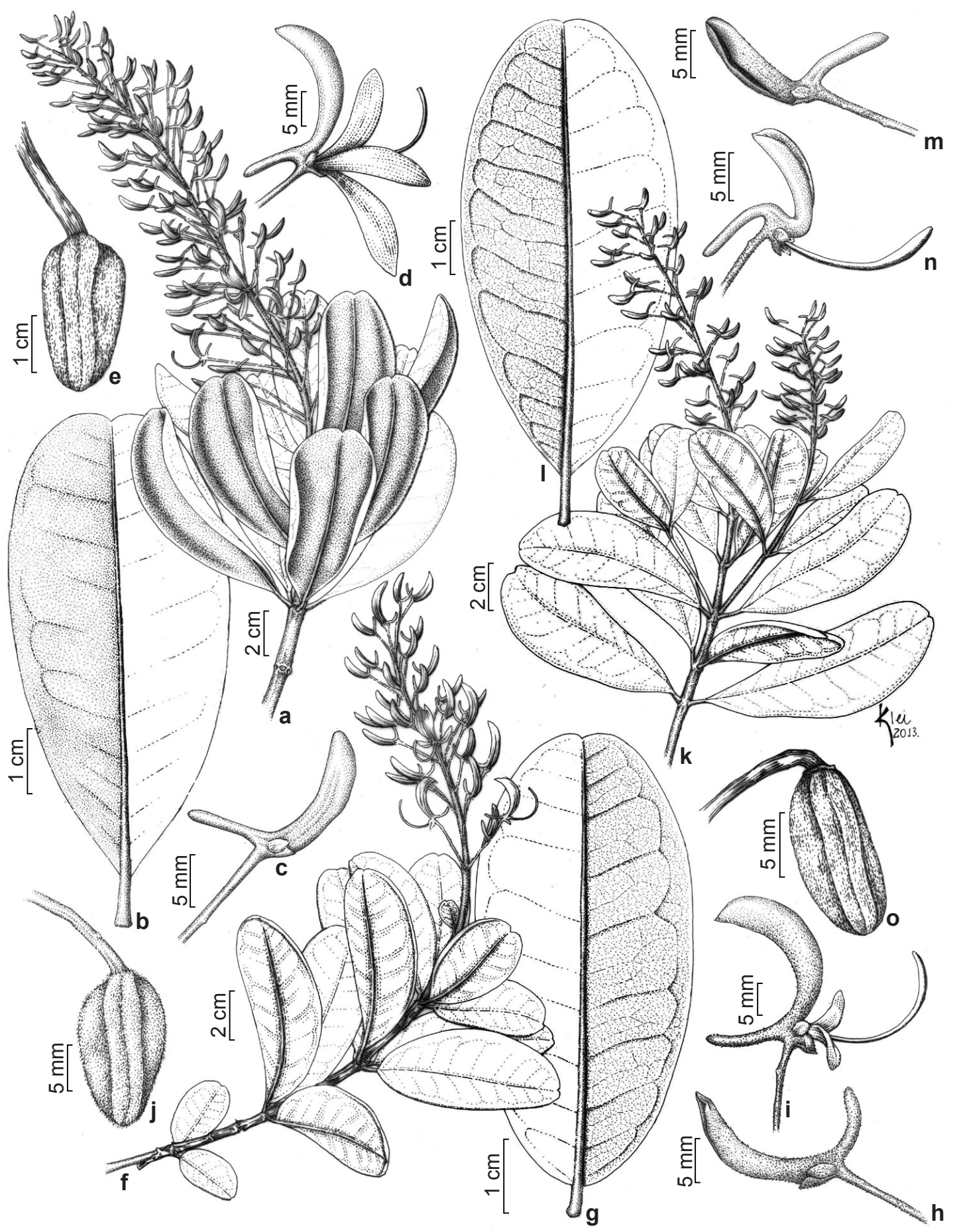

Figura 6 - a-e. Vochysia discolor Warm. - a. ramo; b. face abaxial da folha; c. botão floral; d. flor; e. fruto. f-j. Vochysia elliptica Mart. - f. ramo; g. face abaxial da folha; h. botão floral; i. flor; j. fruto. k-o. Vochysia emarginata (Vahl) Poir. - k. ramo; 1. face abaxial da folha; m. botão floral; n. flor; o. fruto.

Figure 6 - a-e. Vochysia discolor Warm. - a. branch; b. abaxial surface of leaf; c. flower bud; d. flower; e. fruit. f-j. Vochysia elliptica Mart. - f. branch; g. abaxial surface of leaf; h. flower bud; i. flower; j. fruit. k-o. Vochysia emarginata (Vahl) Poir. - k. branch; 1. abaxial surface of leaf; $\mathrm{m}$. flower bud; $\mathrm{n}$. flower; o. fruit. 
pequeno porte, 1,5-5 m alt. Ramos cilíndricos, casca descamante em placas. Folhas em verticilos 3-4-meros, curto-pecioladas a subsésseis, pecíolo 1-3 mm compr., pubescente a glabrescente; lâmina foliar 4-9 × 2,5-4 cm, cartácea, plana, glaucopruinosa, elíptica, oblonga ou obovada, ápice emarginado a arredondado, base cordada, truncada ou arredondada, margem plana, face adaxial glabra, nervura primária plana ou subimpressa, glabra, nervuras secundárias e terciárias planas, face abaxial glabra, nervura primária proeminente, nervuras secundárias e terciárias planas. Inflorescências (5-)10-22 cm compr., tirsos terminais e subterminais, com cíncinos 1-3-floros, eixo, pedúnculos, pedicelos, brácteas e bractéolas pubescentes a glabrescentes; brácteas decíduas. Botões florais 1,5-2 × 0,2-0,3 cm, incurvos, ápice agudo e apiculado; sépala calcarada 1,3-1,6 cm compr., serícea a glabrescente, ápice agudo, sépalas não calcaradas $2-2,5 \times 2 \mathrm{~mm}$, seríceas a glabrescentes, deltoides, ápice agudo; cálcar 6-7 $\mathrm{mm}$ compr., pubérulo a glabrescente, cilíndrico, fortemente incurvo no botão floral, incurvo na flor aberta; pétala central 4-6 $\times 2-3 \mathrm{~mm}$, glabra, amarela, largo-elíptica a obovada, ápice obtuso, base truncada; pétalas laterais $4-5 \times 2 \mathrm{~mm}$, glabras, amarelas, obovadas, ápice obtuso, base truncada. Estame 1,2-1,6 cm compr., filete 1-1,2 cm compr., antera 2-4 mm compr., glabra. Ovário 1-2 $\times 1 \mathrm{~mm}$, piramidal, tomentoso; estilete $1-1,8 \mathrm{~cm}$ compr., piloso na região basal. Cápsula 2,6-3 × 1,5-1,7 cm, elipsoide a ovoide, superfície verruculosa, vilosa (Shimizu \& Yamamoto 2012a).

Material selecionado: Diamantina, Distrito de Senador Mourão, 27.VI.2002, fl. e fr., R.S. Rodrigues \& A.S. Flores 1565 (UEC); Estrada Biri-Biri, 6.VII.1996, fr., V.C. Souza et al. 11886 (UEC); Barão Serra de Capão, 21.V.1931, fl., Y. Mexia 5878 (F, MO, NY, US); Salto Cristal, 19.III.1987, fl., G. Hatschbach et al. 51119 (NY); primeira estrada de terra para Mendanha, 28.IV.2012, fl., D.J.P. Gonçalves et al. 488 (UEC); 28.IV.2012, fl., D.J.P. Gonçalves et al. 505 (UEC); Estrada Mendanha Inhaí, 28.IV.2012, fl., D.J.P. Gonçalves et al. 511 (UEC); Estrada Diamantina - Milho Verde, 30.IV.2012, fl., D.J.P. Gonçalves et al. 528 (UEC); Gouveia, 10.04.1973, fl., W.R. Anderson 8590 (MO, NY, US); Córrego do Tigre, 20.III.1987, fl., G. Hatschbach et al. 51200 (NY); Mineração Tejucana, VI.1989, fl., L.V. Costa et al. 474 (UEC); Estrada Diamantina - Mendanha, 6.VI.1985, fl., J. Semir et al. 17508 (UEC); Rodovia Curvelo Diamantina, 5.VI.1998, fl., V.C. Souza et al. 20918 (ESA); São Gonçalo do Rio Preto, Parque Estadual do Rio Preto, 2.IV.2005, fl., F.N. Costa \& L.G. Lessa 846 (ESA); 23.VI.2011, fl., D.J.P. Gonçalves et al. 105 (DIAM, UEC); 24.VI.2011, fl., D.J.P. Gonçalves et al.
106 (DIAM, UEC); 1.V.2012, fl., D.J.P. Gonçalves et al. 543 (UEC).

Vochysia elliptica tem distribuição ampla no Cerrado, ocorrendo nos estados da BA, GO, MG, MT, TO e no DF. No PD ocorre em cerrado s.s., cerrado rupestre e em campos rupestres, em uma faixa altitudinal que vai de 700 a 1000 $\mathrm{m}$. Coletada com flores de fevereiro a junho e com frutos em junho e julho. Dentre as espécies de Vochysia que ocorrem no PD, pode ser reconhecida principalmente pelo ápice do botão floral agudo e apiculado. Além dessa característica, as folhas curto-pecioladas a subsésseis, glaucopruinosas e de margem plana são as principais características diagnósticas da espécie na área. As inflorescências de $V$. elliptica podem ter (5-)10-22 $\mathrm{cm}$ de comprimento, mas é válido ressaltar que não foi observado um indivíduo com todas as inflorescências medindo $5 \mathrm{~cm}$, observamos que raramente existem algumas inflorescências de um indivíduo com menos de $10 \mathrm{~cm}$, mas há o predomínio de inflorescências com comprimentos maiores que este.

4.5. Vochysia emarginata (Vahl) Poir., Encycl. 8: 682. 1808. Fig. 6k-o

Ilustração: Yamamoto (2009), Shimizu \& Yamamoto (2012a).

Nome popular: cohonga, caixeta, pau-devinho-preto (Stafleu 1948).

Árvores de pequeno a médio porte, $3-8 \mathrm{~m}$ alt., raro arbustos ca. $1 \mathrm{~m}$ alt. Ramos cilíndricos, casca não descamante em placas. Folhas opostas cruzadas, pecioladas, pecíolo 5-15 $\mathrm{mm}$ compr., glabro, pubérulo e glabrescente nas regiões da nervura primária e da base; lâmina foliar (3,5-)6-10 × 2,5-5 cm, cartácea, plana, não glauca, oblonga, elíptica ou obovada, ápice emarginado, base cuneada, atenuada ou levemente decurrente, margem plana, face adaxial glabra, nervura primária impressa, glabra, nervuras secundárias e terciárias planas, face abaxial glabra, nervura primária proeminente, nervuras secundárias promínulas. Inflorescências 9-52 cm compr., tirsos terminais ou terminais e subterminais, com cíncinos 2-4-floros, eixo e axilas pubescentes, pedúnculos, pedicelos, brácteas e bractéolas glabros; brácteas decíduas. Botões florais $1-1,4 \times 0,2-0,3 \mathrm{~cm}$, incurvos, ápice arredondado; sépala calcarada 1,1-1,4 cm compr., pubérula a glabrescente, ápice truncado a retuso, sépalas não calcaradas $1-1,2 \times 1-1,5$ $\mathrm{mm}$, pubescentes, deltoides, ápice arredondado; cálcar $0,7-1 \mathrm{~cm}$ compr., glabro, cilíndrico, reto a 
recurvo no botão, fortemente recurvo, paralelo ou tocando o pedicelo na flor aberta; pétala central 11-15 × 2-3 mm, glabra, amarela, oblonga a espatulada, ápice obtuso a arredondado, base truncada; pétalas laterais 7-13 $\times 2-3 \mathrm{~mm}$, glabras, amarelas, oblongas, ápice obtuso, base truncada. Estame 0,9-1,4 cm compr., filete 0,2-0,4 cm, antera $0,7-1 \mathrm{~cm}$, ciliada na margem. Ovário $1-2$ $\times 1-2 \mathrm{~mm}$, piramidal, glabro; estilete $9-12 \mathrm{~mm}$ compr., glabro. Cápsula ca. $17 \times 7 \mathrm{~mm}$, oblonga, superfície verrucosa, glabra.

Material selecionado: Diamantina, MG-220, 10.IV.1995, fl., R. Mello-Silva et al. 1045 (NY); estrada entre Mendanha e Inhaí, 28.IV.2012, f1., D.J.P. Gonçalves et al. 509 (UEC); Estrada Sopa - São João da Chapada, 29.IV.2012, fl., D.J.P. Gonçalves et al. 516 (UEC); Estrada Diamantina - Milho Verde, 30.IV.2012, fl., D.J.P. Gonçalves et al. 534 (UEC); Itamarandiba, Parque Estadual da Serra Negra, 26.I.2012, fl., D.J.P. Gonçalves et al. 431 (DIAM, UEC); 27.II.2012, fl., D.J.P. Gonçalves et al. 474 (UEC); Rio Vermelho, Pedra Menina, 1.VIII.1985, fl., J.R. Pirani et al. (UEC 152910); São Gonçalo do Rio Preto, Parque Estadual do Rio Preto, trilha para as corredeiras, 25.VI.2011, fl., D.J.P. Gonçalves et al. 108 (DIAM, UEC); Senador Modestino Gonçalves, Serra do Ambrósio, 28.II.2011, fl., D.J.P. Gonçalves et al. 484 (UEC); Serro, $9 \mathrm{~km}$ de Serro em direção a Milho Verde, 11.III.1995, fl., V.C. Souza et al. 8265 (ESA); road to Diamantina, 26.II.1968, fl., H.S. Irwin et al. 20914 (NY, US); Serra da Pedra Redonda, 3.V.1943, fl., L.O. Williams \& V. Assis 6905 (MO, US); 19.III.1963, fl., M. Magalhães 18884 (NY); Rodovia Datas, 9.IV.1995, fl., R. Mello-Silva et al. 1039 (NY); estrada próximo a Serro, 21.XI.2011, fl. e fr., D.J.P. Gonçalves \& M.M.T. Cota 231 (UEC); depois da entrada para Milho Verde, 18.XII.2011, fl. e fr., D.J.P. Gonçalves et al. 372 (UEC); Estrada Milho Verde - Serro, 30.IV.2012, fl., D.J.P. Gonçalves et al. 537 (UEC).

Vochysia emarginata ocorre em MG e BA (Kawasaki 1995; Shimizu \& Yamamoto 2012a) e no PD foi coletada com flores de janeiro a maio, junho e agosto e com frutos em novembro e dezembro. Foi encontrada em campos rupestres e em formações florestais associadas a corpos d'água em elevações de 700 a 1300 m. No Parque Estadual de Serra Negra, situado no norte do PD, $V$. emarginata foi encontrada em campo rupestre de "carrasco" e "areia branca" e os indivíduos deste local apresentaram lâminas foliares menores $(3,5-$ $6,5 \mathrm{~cm}$ compr.) que os representantes da espécie encontrados em outras localidades do PD. Na área de estudo, $V$. emarginata pode ser reconhecida pela associação das seguintes características: folhas opostas e ápice do botão floral arredondado.
4.6. Vochysia gardneri Warm. in Mart. \& Eichler, Fl. bras. 13(2): 70. $1875 . \quad$ Fig. 7a-e Ilustração: Yamamoto (2009).

Árvores de pequeno porte, 1,5-7 m alt. Ramos cilíndricos, quadrangulares quando jovens, casca descamante em placas. Folhas em verticilos 4-meros, pecioladas, pecíolo 10-13 mm compr., tomentoso; lâmina foliar 8-13 × 3,5-6 $\mathrm{cm}$, coriácea, plana, não glauca, oblongo-elíptica, ápice emarginado, base atenuada ou aguda, margem plana, face adaxial glabra, nervura primária plana ou subimpressa, gríseo-tomentúlea, nervuras secundárias e terciárias planas, face abaxial gríseo-tomentosa a glabrescente, nervura primária proeminente, nervuras secundárias e terciárias promínulas a planas. Inflorescências $15-26 \mathrm{~cm}$ compr., tirsos terminais ou subterminais, com cíncinos 2-3-floros, eixo, pedúnculos, pedicelos, brácteas e bractéolas tomentosos a pulverulentos; brácteas decíduas. Botões florais 1,3-1,8 $\times$ $0,2-0,3 \mathrm{~cm}$, retos, ápice agudo; sépala calcarada 5-6,8 mm compr., tomentosa, ápice obtuso ou retuso, sépalas não calcaradas $2-1,5 \times 2-2,5 \mathrm{~cm}$, tomentosas, ovadas, ápice agudo; cálcar $7 \mathrm{~mm}$ compr., tomentoso, cilíndrico, incurvo a fortemente incurvo no botão, incurvo na flor aberta; pétala central 5-8 × 2-4 mm, glabra, amarela, obovada, ápice obtuso, base truncada; pétalas laterais 5-7 $\times$ 3-4 mm, glabras, amarelas, oblongas a obovadas, ápice obtuso a arredondado, base truncada. Estame $1,1-1,7 \mathrm{~cm}$ compr., filete $0,2-0,3 \mathrm{~cm}$ compr., antera 0,9-1,4 cm compr., glabra. Ovário ca. $2 \times 1-2$ $\mathrm{mm}$, piramidal, seríceo; estilete $1-1,5 \mathrm{~cm}$ compr., glabro. Cápsula ca. 2,2 × 1,2 cm, oblongo-elíptica, superfície lisa, densamente ferrugíneo tomentosa. Material examinado: Diamantina, 28.IV.2012, fl. e fr., D.J.P. Gonçalves et al. 494 (UEC).

Vochysia gardneri ocorre no Brasil, nos estados da BA, GO, MA, MG, MT, PI e TO. Ocorre principalmente em cerrado s.s. no estado de Goiás e no PD foi coletada na região de Mendanha, município de Diamantina. Encontrada com flores e frutos imaturos em abril em elevações entre 690 e $870 \mathrm{~m}$. Dentre as espécies de $V$. subseção Decorticantes (com casca descamante e ovário piloso) que ocorrem no $\mathrm{PD}, V$. gardneri pode ser reconhecida por apresentar pecíolos com 1-1,3 cm de comprimento, as folhas não glaucas e a forma da lâmina foliar oblongo-elíptica. Além disso, o caule cinza claro pode ser utilizado para diferenciar $V$. gardneri de $V$. elliptica, que apresenta caule de coloração castanha. A coleta Gonçalves et al. 494 não apresenta algumas características típicas 
de $V$. gardneri, como folhas conduplicadas, mas foi mantida como tal por apresentar sobreposição do comprimento do pecíolo e ápice do botão floral acuminado, características que levam a $V$. gardneri a chave de Stafleu (1948). Mais estudos, incluindo análises de filogenia molecular, em desenvolvimento, poderão contribuir para a circunscrição a ser adotada para esse material.

4.7. Vochysia oppugnata (Vell.) Warm. in Mart. \& Eichler, Fl. bras. 13(2): 87. 1875.

Fig. $7 \mathrm{f}-\mathrm{i}$

Ilustração: Vianna (1980).

Nomes populares: canela-santa, cinzeiro, congonha-do-campo, congonheiro, guaruba, jacatirãobranco, louro-d'água, murici, murici-bariga-d'água, murici-branco, muricica, pau-de-brincos, pau-decinza, pau-de-lágrima, rabo-de-arara, rabo-de-tucano (Vianna 2002).

Árvores de grande porte, 7-19 m alt. Ramos cilíndricos, quadrangulares quando jovens, casca não descamante em placas. Folhas em verticilos 4-meros, pecioladas, pecíolo $18-25 \mathrm{~mm}$ compr., glabro; lâmina foliar 9,5-14,5 × 3-5 cm, cartácea, plana, não glauca, espatulada ou oblonga, ápice emarginado ou arredondado, base atenuada, margem plana, face adaxial glabra, nervura primária impressa, glabra, nervuras secundárias e terciárias promínulas, face abaxial glabra, nervura primária proeminente, nervuras secundárias e terciárias promínulas. Inflorescências ca. $17 \mathrm{~cm}$ compr., tirsos terminais, com cíncinos 2-5-floros, eixo, pedúnculos, pedicelos, brácteas e bractéolas pubérulos a glabrescentes; brácteas decíduas. Botões florais ca. 1,7 ×0,2 cm, incurvos, ápice agudo; sépala calcarada ca.1,5 cm compr., glabra, ápice truncado a retuso, sépalas não calcaradas ca. $1,3-1,5 \times 1,2-1,5 \mathrm{~cm}$, pubérulas a glabrescentes, deltoides, ápice agudo a acuminado; cálcar ca. $10 \mathrm{~mm}$ compr., pubérulo e glabrescente, cilíndrico, fortemente incurvo no botão e fortemente recurvo na flor aberta; pétala central ca. $9 \times 2$ $\mathrm{mm}$, glabra, amarela, oblongo-espatulada, ápice arredondado ou obtuso, base truncada; pétalas laterais ca. $8 \times 2 \mathrm{~mm}$, glabras, amarelas, oblongo-espatuladas, ápice arredondado ou obtuso, base truncada. Estame ca. $1,4 \mathrm{~cm}$ compr., filete ca. $0,2 \mathrm{~cm}$ compr., antera ca. $1,2 \mathrm{~cm}$ compr., ciliada na margem. Ovário ca. $1 \times 1$ $\mathrm{mm}$, piramidal, glabro; estilete ca. $1,3 \mathrm{~cm}$ compr., glabro. Cápsula ca. 1,9 $\times 0,7 \mathrm{~cm}$, oblonga, superfície levemente verrucosa, glabra.

Material examinado: Senador Modestino Gonçalves, 28.II.2012, veg., D.J.P. Gonçalves et al. 487 (UEC).

Material adicional examinado: BAHIA: Itamaraju, 12.I.1977, fl., R.M. Harley et al. 17866 (UEC); São Paulo,
São Sebastião, 19.IV.2000, fr., G. Franco et al. 2923 (UEC).

Vochysia oppugnata ocorre no Brasil, nos estados da BA, MG, RJ, SP e no DF (Barbosa 1999; Vianna 2002; França 2005). Na Estação Ecológica Mata dos Ausentes (EEMA), localizada no município de Senador Modestino Gonçalves (norte do PD), foi encontrada uma população desta espécie, a ca. $850 \mathrm{~m}$ de altitude. Vochysia oppugnata é a única espécie da família que ocorre em Floresta Atlântica da EEMA, sendo que os indivíduos de $V$. tucanorum (espécie que pode ser encontrada tanto em Cerrado quanto em Floresta Atlântica) lá encontrados estavam em formações florestais de Cerrado. No PD V. oppugnata pode ser confundida com $V$. tucanorum, da qual se diferencia pelo grande porte das árvores (até 19 $\mathrm{m}$ ), por ocorrer estritamente em Floresta Atlântica e por ter pecíolos com pelo menos $1,8 \mathrm{~cm}$ de comprimento. Os exemplares de $V$. tucanorum do PD tem no máximo $12 \mathrm{~m}$ de altura, não ocorrem em áreas de Floresta Atlântica e possuem pecíolos de até ca. 0,6 cm de comprimento.

4.8. Vochysia pygmaea Bong., Mém. Acad. Imp. Sci. Saint-Pétersbourg, Sér. 6, Sci. Math., Seconde Pt. Sci. Nat. 3(2): 7, t. 4. $1840 . \quad$ Fig. 7j-n Ilustração: Shimizu \& Yamamoto (2012a).

Subarbustos ou arbustos eretos, normalmente não ramificados, $0,3-1(-2) \mathrm{m}$ alt. Ramos cilíndricos, casca não descamante em placas. Folhas em verticilos 3-meros, raramente 4-5-meros, pecioladas, pecíolo ca. $2 \mathrm{~mm}$ compr., glabro; lâmina foliar 2,9-3,2 × 1,5-2,5 cm, coriácea, plana, glauco-pruinosa, obovada a elíptica, ápice truncado, retuso ou emarginado, base cuneada, margem plana, face adaxial glabra, nervura primária impressa, glabra, nervuras secundárias e terciárias planas inconspícuas, face abaxial glabra, nervura primária proeminente, nervuras secundárias e terciárias planas. Inflorescências 11-12 cm compr., tirsos terminais, com cíncinos 1-3-floros, eixo, pedúnculos, pedicelos, brácteas e bractéolas esparsamente pubescentes; brácteas decíduas. Botões florais ca. 1,5 ×0,2 cm, levemente incurvos, ápice arredondado; sépala calcarada 1,4-1,5 cm compr., pubescente a glabrescente, ápice truncado, sépalas não calcaradas $1-1,5 \times$ 1-2 mm, pubescentes, deltoides, ápice agudo a arredondado; cálcar 4-6 × $1 \mathrm{~mm}$ compr., pubescente, cônico, reto; pétala central $15 \times 2$ $\mathrm{mm}$, glabra, ciliada na margem, na região distal, amarela, oblonga, ápice obtuso, base truncada; 


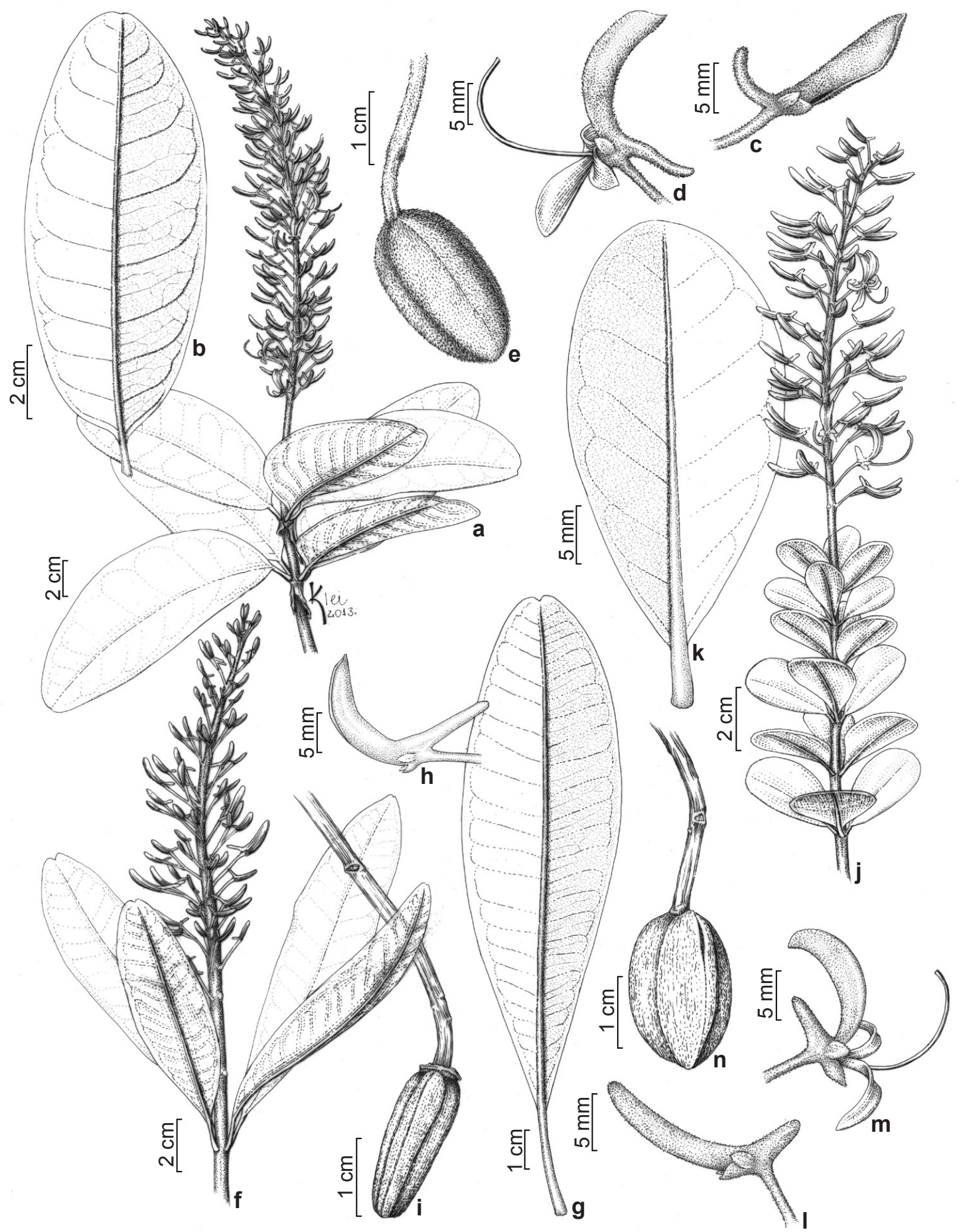

Figura 7 -a-e. Vochysia gardneri Warm. - a. ramo; b. face abaxial da folha; c. botão floral; d. flor; e. fruto. f-i. Vochysia oppugnata (Vell.) Warm. - f. ramo; g. face abaxial da folha; h. botão floral; i. fruto. j-n. Vochysia pygmaea Bong. - j. ramo; k. face abaxial da folha; 1 . botão floral; $\mathrm{m}$. flor; $\mathrm{n}$. fruto.

Figure 7 -a-e. Vochysiagardneri Warm. - a. branch; b. abaxial surface of leaf; c. flower bud; d. flower; e. fruit. f-i. Vochysia oppugnata (Vell.) Warm. -f. branch; g. abaxial surface of leaf; h. flower bud; i. fruit. j-n. Vochysia pygmaea Bong. -j. branch; k. abaxial surface of leaf; 1. flower bud; m. flower; $n$. fruit. 
pétalas laterais $7-13 \times 1 \mathrm{~mm}$, ciliadas na margem, na região distal, amarelas, oblongas, ápice obtuso, base truncada. Estame 1,3-1,4 cm compr., filete $0,2-0,3 \mathrm{~cm}$ compr., antera $1,1-1,3 \mathrm{~cm}$ compr., ciliada na margem. Ovário ca. $1 \times 1 \mathrm{~mm}$, piramidal, glabro; estilete ca. 1,2 cm compr., glabro. Cápsula ca. 1,8-2 × 1,2-1,3 cm, oblongo-elíptica, superfície verrucosa, glabra (Shimizu \& Yamamoto 2012a). Material examinado: Diamantina, 15.XII.1979, fl., $G$. Martinelli \& G. Smith 6314 (RB).

Ocorre no estado de Minas Gerais, coletada predominantemente na região da Serra do Cipó e uma vez no sul do Planalto de Diamantina. Este material foi coletado em um local próximo ao limite norte da Serra do Cipó, e após as viagens de coleta realizadas neste trabalho, a espécie não foi localizada novamente. No PD foi coletada com flores em dezembro. Vochysia pygmaea, $V$. rotundifolia e Vochysia sp. são subarbustos ou arbustos, sendo que apenas Vochysia sp. tem hábito decumbente e as outras duas possuem hábito ereto. Os indivíduos de $V$. pygmaea geralmente não têm ramificações e geralmente medem $1 \mathrm{~m}$ de altura, já os indivíduos de $V$. rotundifolia têm ramificações e dimensões maiores, medindo ca. 2,3 m. Além disso, as folhas de $V$. pygmaea são geralmente menores, obovadas a elípticas, enquanto $V$. rotundifolia possui folhas maiores e orbiculares.

4.9. Vochysia rotundifolia Mart., Nov. Gen. Sp. Pl. 1: 140, t. 83. 1826. Fig. 8a-e Ilustração: Shimizu \& Yamamoto (2012a).

Arbustos eretos e ramificados, ca. 2,3 $\mathrm{m}$ alt. Ramos cilíndricos ou quadrangulares, casca não descamante em placas. Folhas em verticilos 3-meros, subsésseis, pecíolo ca. $1 \mathrm{~mm}$ compr., glabro; lâmina foliar 2,3-4,4 × $2-3 \mathrm{~cm}$, coriácea, plana, não glauca, orbicular, ápice emarginado, base cordada, margem revoluta, face adaxial glabra, nervura primária impressa, glabra, nervuras secundárias e terciárias promínulas, face abaxial glabra, nervura primária proeminente, nervuras secundárias e terciárias promínulas. Inflorescências 14-15 cm compr., tirsos terminais e subterminais, com cíncinos 2-4-floros, eixo, pedúnculo, pedicelos, brácteas e bractéolas glabros, pubescentes a glabrescentes apenas nas axilas; brácteas decíduas. Botões florais 1,5-1,8 × 0,3 $\mathrm{cm}$, incurvos, ápice arredondado; sépala calcarada 1,6-1,7 cm compr., glabra, ápice truncado a retuso, sépalas não calcaradas ca. $1,5 \times 1,5 \mathrm{~mm}$, glabras, deltoides, ápice agudo; cálcar 7-8 $\mathrm{mm}$ compr., glabro, cilíndrico, reto no botão e fortemente recurvo na flor aberta; pétala central 16-18 $\times 3 \mathrm{~mm}$, glabra, ciliada na margem, amarela, espatulada, ápice obtuso, base truncada; pétalas laterais 10-12 $\times 2-3 \mathrm{~mm}$, glabras, amarelas, espatuladas, ápice obtuso, base truncada. Estame 1,5-1,7 cm compr., filete $0,3-0,4 \mathrm{~cm}$ compr., antera $1,2-1,3 \mathrm{~cm}$ compr., ciliada nas margens. Ovário $1 \times 1 \mathrm{~mm}$, piramidal, glabro; estilete 1,6-1,7 cm, glabro. Cápsula $1,2-1,5 \times 0,5-0,8 \mathrm{~cm}$, oblongo-ovoide, superfície verruculosa, glabra (Shimizu \& Yamamoto 2012a). Material examinado: Diamantina, Biri-Biri, 25.II.1975, fl., G. Hatschbach et al. 36501 (MO, NY); ca. $2 \mathrm{~km} \mathrm{~S}$ of São João da Chapada, 26.III.1970, fl., H.S. Irwin et al. 28375 (MO, NY); Salto Cristal, 19.III.1987, fl., G. Hatschbach et al. 51222 (MO, US); 23.IV.2012, fl., M.M.T. Cota et al. 344 (DIAM, UEC).

Material adicional examinado: Jaboticatubas, 20.VIII.1972, fl., A.B. Joly \& J. Semir CFSC 2966 (UEC).

Ocorre em Minas Gerais (Shimizu \& Yamamoto 2012a), principalmente nos campos rupestres da região da Serra do Cipó e menos comumente no PD. Nesta área foi coletada no Parque Estadual do Biribiri, próximo à cachoeira dos Cristais e, apesar de existir uma coleta (H.S. Irwin et al. 28375) proveniente de São João da Chapada, esta espécie não foi encontrada no local durante as expedições realizadas neste trabalho. Coletada em elevações de 1150-1300 m, com flores de fevereiro a abril. Assemelha-se a V. pygmaea (vide comentários desta espécie).

4.10. Vochysia rufa Mart., Nov. Gen. Sp. Pl. 1: 144 , t. 86. 1826.

Fig. 8f-1

Ilustração: Barbosa (1999), Yamamoto (2009), Shimizu \& Yamamoto (2012a).

Nome popular: pau-doce (Stafleu 1948), vinhatu (Barbosa 1999).

Árvores de pequeno porte, 1-4 m alt. Ramos cilíndricos, casca descamante em placas. Folhas em verticilos (3-)5-meros, pecioladas, pecíolo 15-30 $\mathrm{mm}$ compr., tomentoso a pulverulento; lâmina foliar 10-20 × 2,5-8,5 cm, cartácea, conduplicada, não glauca, oblonga, espatulada ou oblongoelíptica, ápice obtuso, arredondado ou retuso, base decurrente, atenuada ou aguda, margem plana, face adaxial tomentosa a glabrescente, nervura primária impressa, tomentosa a glabrescente, nervuras secundárias e terciárias planas, face abaxial tomentosa, pulverulenta a glabrescente, nervura primária proeminente, nervuras secundárias e terciárias promínulas. Inflorescências $27-48 \mathrm{~cm}$ compr., tirsos terminais, com cíncinos 2-4-floros, eixo, pedúnculos, pedicelo, brácteas e bractéolas 


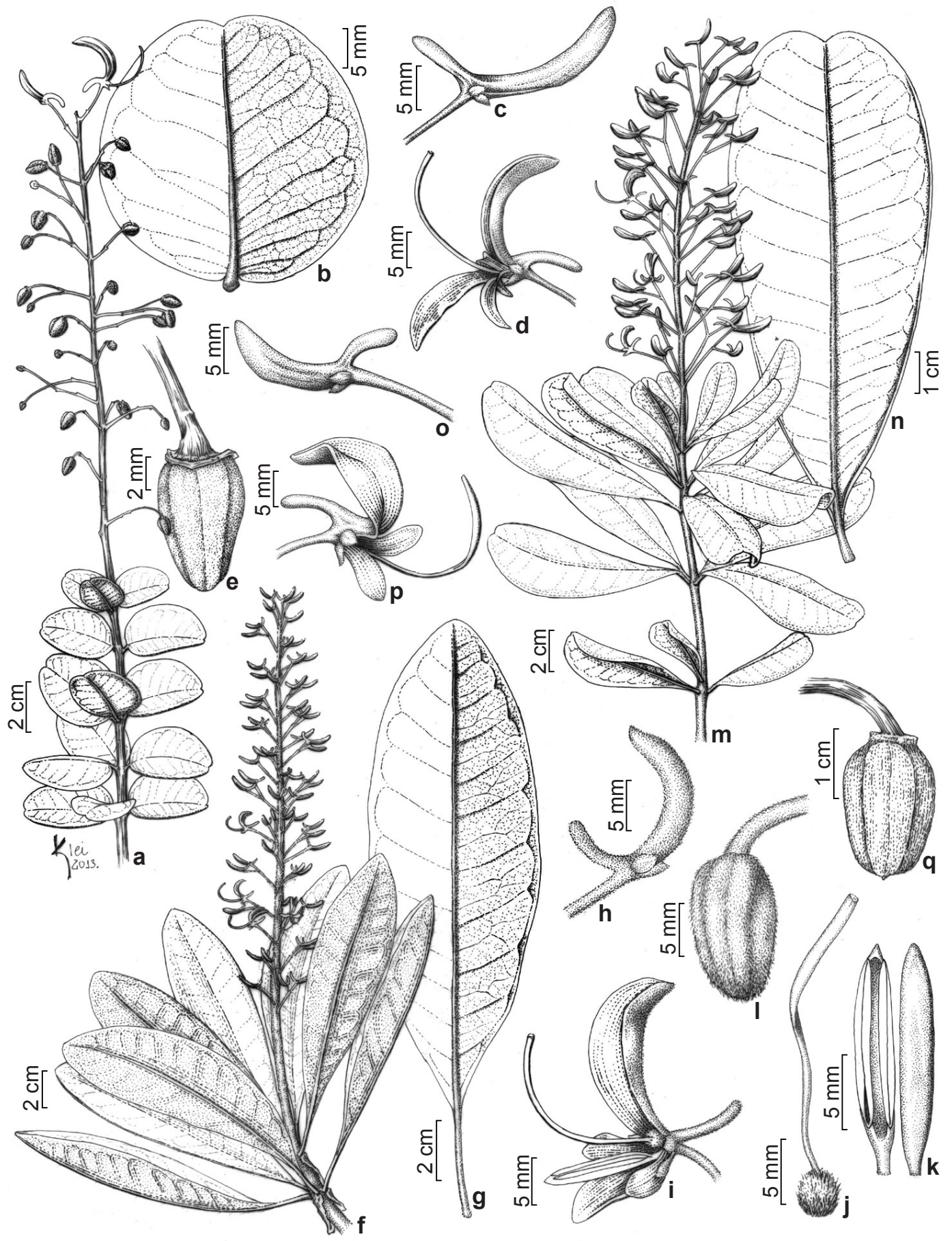

Figura 8 - a-e. Vochysia rotundifolia Mart. - a. ramo; b. face abaxial da folha; c. botão floral; d. flor; e. fruto. f-1. Vochysia rufa Mart. - f. ramo; g. face abaxial da folha; h. botão floral; i. flor; j. gineceu; k. estame em duas vistas; 1 . fruto. m-q. Vochysia thyrsoidea Pohl. - m. ramo; n. face abaxial da folha; o. botão floral; p. flor; q. fruto.

Figure 8 - a-e. Vochysia rotundifolia Mart. - a. branch; b. abaxial surface of leaf; c. flower bud; d. flower; e. fruit. f-l. Vochysia rufa Mart. - f. branch; g. abaxial surface of leaf; h. flower bud; i. flower; j. gynoecium; k. stamen in two views; 1. fruit. m-q. Vochysia thyrsoidea Pohl. - m. branch; $n$. abaxial surface of leaf; o. flower bud; p. flower; q. fruit. 
densamente tomentosos; brácteas decíduas. Botões florais 1,1-1,4 ×0,2 cm, incurvos, ápice arredondado; sépala calcarada ca. 1,5 cm compr., densamente tomentosa, ápice obtuso a truncado, sépalas não calcaradas 1,3-1,9 mm compr., densamente tomentosas, deltoides, ápice obtuso; cálcar 6-7 mm compr., densamente tomentoso, cilíndrico, reto a levemente incurvo no botão, incurvo na flor aberta; pétala central 7-9 × 4-5 $\mathrm{mm}$, glabra, amarela, oblongo-elíptica, ápice obtuso, base truncada; pétalas laterais 6-7 × 3-4 $\mathrm{mm}$, glabras, amarelas, espatuladas, ápice obtuso a arredondado, base truncada. Estame 1,4-1,6 cm compr., filete 0,3-0,4 cm compr., antera 1,1-1,2 cm compr., glabra. Ovário ca. $2 \times 2 \mathrm{~mm}$, subgloboso, densamente tomentoso; estilete 1,1-1,4 cm compr., glabro. Cápsula ca. 3,4 × $2 \mathrm{~cm}$, ovoide, superfície verrucosa, tomentosa e glabrescente.

Material selecionado: Diamantina, primeira estrada de terra para Mendanha, 28.IV.2012, f1., D.J.P. Gonçalves et al. 491 (UEC).

Material adicional examinado: Garapu, 2.X.1964, fr., H.S. Irwin \& T.R. Soderstrom (UEC 23998).

Vochysia rufa ocorre na Bolívia e no Brasil, nos seguintes estados: BA, GO, MA, MG, MS, MT, PA, PI, RO, SP, TO e no DF (Shimizu \& Yamamoto 2012a), encontrada em cerrado s.s. No PD foi coletada apenas em terrenos baixos, próximo a Mendanha (município de Diamantina) em elevação de 600-740 m. Foi coletada com flores e frutos imaturos em abril. Dentre as espécies que apresentam a casca dos ramos descamante em placas e ovário piloso ( $V$. elliptica, $V$. gardneri, $V$. rufa e Vochysia sp.), pode ser reconhecida pela associação das seguintes características: folhas conduplicadas, em verticilos (3-)5-meros e pecíolos de 1,7 a 2,3 cm compr.

4.11. Vochysia thyrsoidea Pohl, Pl. Bras. Icon. Descr. 2: 24, t. 115. 1828 v. $1829 . \quad$ Fig. 8m-q

Ilustração: Pohl (1828 ou 1829), Barbosa (1999), Gonçalves et al. (2013).

Nome popular: goma-arabica (MG, GO), cachoeiro-do-campo (MG), araripe (MG), pau-devinho (GO), gomeira (GO) (Stafleu 1948).

Árvores de pequeno a médio porte, 1-5 m alt. Ramos cilíndricos, casca não descamante em placas. Folhas em verticilos 4-meros, pecioladas, pecíolo 11-14 mm compr., pubescente; lâmina foliar 6-16 × 2,5-4,5 cm, coriácea, plana, não glauca, elíptica, oblonga ou espatulada, ápice emarginado, arredondado ou truncado, base cuneada ou atenuada, margem revoluta, face adaxial glabra, nervura primária impressa, tomentosa, nervuras secundárias e terciárias planas (às vezes inconspícuas), face abaxial glabra ou gríseo-tomentúlea a glabrescente, nervura primária proeminente, gríseo-tomentúlea, nervuras secundárias e terciárias planas a promínulas (às vezes inconspícuas). Inflorescências ca. $17 \mathrm{~cm}$ compr., tirsos terminais, com cíncinos 2-3-floros, eixo, pedúnculos, brácteas e bractéolas pubérulos a glabrescentes, pedicelos glabros; brácteas decíduas. Botões florais 1,3-1,9 × 0,2-0,4 cm, incurvos, ápice arredondado; sépala calcarada 1,4-2,1 cm compr., glabra, ápice obtuso, sépalas não calcaradas 1,5-2 × 1,8-2 mm, glabras, deltoides a ovais, ápice agudo a obtuso; cálcar 6-7 mm compr., glabro, cilíndrico, reto a levemente recurvo no botão, fortemente recurvo na flor aberta; pétala central 16-21 × 2-4 mm, glabra, amarela, espatulada, ápice agudo a obtuso, base truncada; pétalas laterais 11-13 × 1-3 mm, glabras, amarelas, espatuladas, ápice agudo a obtuso, base truncada. Estame 1,5-2,2 cm compr., filete $0,3-0,4 \mathrm{~cm}$ compr., antera 1,2-1,8 cm compr., ciliada na margem. Ovário ca. $2 \times 2 \mathrm{~mm}$, piramidal, glabro; estilete 1,5-1,7 cm compr., glabro. Cápsula ca. 2,5 × 1,5 cm, oblonga ou oblongo-ovoide, verrucosa, glabra.

Material selecionado: Datas, entre o trevo e Datas, 11.XII.2011, fl., D.J.P. Gonçalves et al. 280 (DIAM, UEC); Distrito de Tombadouro, 11.XII.2011, fl., D.J.P. Gonçalves et al. 287 (DIAM, UEC); Diamantina, Estrada Diamantina - Conselheiro Mata, 8.VII.2001, fr., V.C. Souza et al. 25396 (UEC); Estrada Conselheiro Mata Diamantina, 23.II.1986, fr., N.L. Menezes et al. CFCR 9540 (NY, UEC); road to Gouveia, 13.I.1969, fl., H.S. Irwin et al. 21847 (F, NY); estrada pouco depois de Sopa, 15.XI.2011, fl., D.J.P. Gonçalves \& M.M.T. Cota 146 (DIAM, UEC); Estrada Mendanha - Inhaí, 16.XI.2011, fl., D.J.P. Gonçalves \& M.M.T. Cota 163 (DIAM, UEC); $2 \mathrm{~km}$ depois da entrada de Sopa, 10.XII.2011, fl., D.J.P. Gonçalves \& M.M.T. Cota 245 (UEC); Estrada Conselheiro Mata - Diamantina, 12.XII.2011, fl., D.J.P. Gonçalves \& C.C. Mattioli 296 (UEC); Parque Nacional das Sempre Vivas, 16.XII.2012, fl., D.J.P. Gonçalves et al. 353 (UEC); Conselheiro Mata, 22.I.2012, fl. e fr., D.J.P. Gonçalves et al. 379 (DIAM, UEC); Estrada Sopa - São João da Chapada, 29.IV.2012, veg., D.J.P. Gonçalves et al. 521 (UEC); Gouveia, estrada entre Gouveia e o Trevão, 10.XII.2011, fl., D.J.P. Gonçalves \& M.M.T. Cota 261 (DIAM, UEC); estrada entre Gouveia e o Trevão, 10.XII.2011, fl., D.J.P. Gonçalves \& M.M.T. Cota 265 (DIAM, UEC); estrada entre Chapadinha e Barão de Guaicuí, 13.XII.2011, fl., D.J.P. Gonçalves et al. 303 (UEC); estrada para Barão de Guaicuí, 13.XII.2011, fl., D.J.P. Gonçalves et al. 306 (UEC); Serro, Milho Verde, 21.XI.2011, fl., D.J.P. Gonçalves \& M.M.T. Cota 230 (UEC). 
Ocorre no Brasil, nos estados da BA, CE, GO, MG, SP e no DF (Gonçalves et al. 2013), encontrada tipicamente em campos rupestres e com menos frequência em cerrado s.s. No PD foi coletada em elevações entre 700 e $1330 \mathrm{~m}$, com flores de novembro a janeiro e com frutos em novembro e fevereiro. Pode ser reconhecida por apresentar folhas com face abaxial glabra ou indumentada, neste caso os tricomas são gríseos e a lâmina não assume aspecto discolor. Dentre as espécies que ocorrem no PD, Vochysia discolor é a que mais se assemelha a $V$. thyrsoidea, pelas folhas dispostas em verticilos 4-meros e margem das folhas revoluta (vide comentários de $V$. discolor).

4.12. Vochysia tucanorum Mart., Nov. Gen. Sp. Pl. 1: 142, t. 85. 1826.

Fig. 9a-e

Ilustração: Vianna (1980), Barbosa (1999), Gonçalves et al. (2013).

Nomes populares: amarelinho, canelasanta, cangirana, congonha, congonha-cachimbo, congonha-caixeta, congonha-murici, coxa-defrango, falsa-pororoca, flor-de-tucano, leiteirado-campo, murici-branco, pau-de-caxeta, pau-detucano, pau-dos-tucanos, vinheiro (Vianna 2002).

Árvores de pequeno a médio porte, 2-12 m alt. Ramos cilíndricos, casca não descamante em placas. Folhas em verticilos 4-meros, pecioladas, pecíolo 3-6 mm compr., pubérulo ou glabrescente; lâmina foliar $6-8,5 \times 2-3 \mathrm{~cm}$, cartácea, plana, não glauca, espatulada, ápice emarginado, base decurrente, atenuada ou cuneada, margem revoluta no terço proximal da lâmina, face adaxial glabra, nervura primária impressa, tomentúlea, nervuras secundárias e terciárias promínulas, face abaxial glabra, nervura primária proeminente, nervuras secundárias e terciárias planas. Inflorescências 9-27,5 cm compr., tirsos terminais e subterminais, com cíncinos 2-4-floros, eixo, pedúnculos, pedicelos, brácteas e bractéolas pubescentes a glabrescentes; brácteas decíduas. Botões florais $1,1-1,5 \times 0,1-0,2 \mathrm{~cm}$, incurvos, ápice agudo; sépala calcarada 1,2-1,5 cm compr., glabra, ápice truncado, sépalas não calcaradas ca. $1 \times 1 \mathrm{~mm}$, glabras, deltoides, ápice arredondado; cálcar 6-8 $\mathrm{mm}$ compr., glabro, cilíndrico, reto a incurvo no botão e fortemente recurvo, podendo tocar ou ir além do pedicelo na flor aberta; pétala central 10-12 × 1-3 mm, glabra, amarela, espatulada, ápice obtuso, base truncada; pétalas laterais 6-7× 2-4 mm, glabras, amarelas, oblongas a espatuladas, ápice obtuso, base truncada. Estame 1,1-1,4 cm compr., filete $0,3-0,4 \mathrm{~cm}$ compr., antera $0,8-1$ cm compr., glabra ou ciliada na margem. Ovário ca. $1 \times 1 \mathrm{~mm}$, piramidal, glabro; estilete $0,9-1,4$ cm compr., glabro. Cápsula 1,7-1,8 × 0,8-1 cm, oblongo-ovoide, superfície verrucosa, glabra.

Material selecionado: Datas, Rodovia BR-259, 17.III.1987, fl., G. Hatschbach et al. 51057 (NY); 6.II.1972, fl., W.R. Anderson et al. 35562 (NY); Rodovia Datas - Serro, 8.I.1988, fl., R. Mello-Silva et al. (UEC 53845); depois do trevo em direção à Diamantina, 11.XII.2011, fl., D.J.P. Gonçalves et al. 278 (DIAM, UEC); estrada entre Diamantina e Serro, 18.XII.2011, f1., D.J.P. Gonçalves et al. 373 (UEC); Diamantina, 6.V.1931, fr., Y. Mexia 5767 (F, MO, NY, US); Serra do Espinhaço, 9.VI.1973, fl., P. Occhioni 5627 (F); road to Curvelo, 23.XII.1959, fl., B. Maguire et al. 44771 (NY); 28.III.1970, fl., H.S. Irwin et al. 28441 (NY); estrada para São João da Chapada, 14.I.1998, fl., J.R. Pirani et al. 3976 (UEC); trevo para Datas, 2.I.1987, fl., G. Pedralli (BHCB 14005, UEC 63182); estrada entre Guinda e Sopa, 15.XI.2011, fl., D.J.P. Gonçalves \& M.M.T. Cota 143 (DIAM, UEC); Estrada Mendanha - Inhaí, 16.XI.2011, fl., D.J.P. Gonçalves \& M.M.T. Cota 167 (UEC); Estrada ponte do Acaba Mundo - Chapada do Couto, 14.XII.2011, fl., D.J.P. Gonçalves et al. 323 (UEC); Estrada Conselheiro Mata - Diamantina, 24.I.2012, fl., D.J.P. Gonçalves et al. 413 (DIAM, UEC); Gouveia, estrada entre Gouveia e Cuiabá, 10.XII.2011, fl., D.J.P. Gonçalves \& M.M.T. Cota 246 (DIAM, UEC); 10.XII.2011, fr., D.J.P. Gonçalves \& M.M.T. Cota 248 (UEC); estrada entre Gouveia e o Trevão, 10.XII.2011, fl., D.J.P. Gonçalves \& M.M.T. Cota 271 (DIAM, UEC); Estrada Cuiabá - Barão de Guaicuí, 13.XII.2011, fl., D.J.P. Gonçalves et al. 301 (UEC); estrada entre Chapadinha e Barão de Guaicuí, 13.XII.2011, fl., D.J.P. Gonçalves et al. 305 (UEC); São Gonçalo do Rio Preto, Parque Estadual do Rio Preto, 20.VIII.2005, fl., E.B. Foresto et al. 46 (UEC); Mineração Tejucana, 5.I.1989, fl., L.V. Costa et al. 473 (UEC); Senador Modestino Gonçalves, Estação Ecológica Mata dos Ausentes, 25.I.2012, fl., D.J.P. Gonçalves et al. 416 (DIAM, UEC); Serro, Estrada São Gonçalo do Rio das Pedras - Milho Verde, 21.XI.2011, fl., D.J.P. Gonçalves \& M.M.T. Cota 228 (DIAM, UEC); estradinha próxima à entrada para Presidente Kubitschek, 11.XII.2011, fl., D.J.P. Gonçalves et al. 272 (DIAM, UEC); Estrada Diamantina - Milho Verde, 30.IV.2012, fr., D.J.P. Gonçalves et al. 536 (UEC).

Ocorre na Bolívia, no Paraguai e no Brasil, nos estados da BA, ES, GO, MG, MS, MT, PR, RJ, SP, TO e no DF (Stafleu 1948; Shimizu \& Yamamoto 2012a). No PD foi coletada com flores de novembro a fevereiro e abril e com frutos em dezembro e abril, em elevações que variam de 680 a $1330 \mathrm{~m}$. Ocorre normalmente em formações florestais associadas a cursos d'água, menos comumente encontrada em cerrado s.s. Vochysia tucanorum pode ser reconhecida por apresentar 


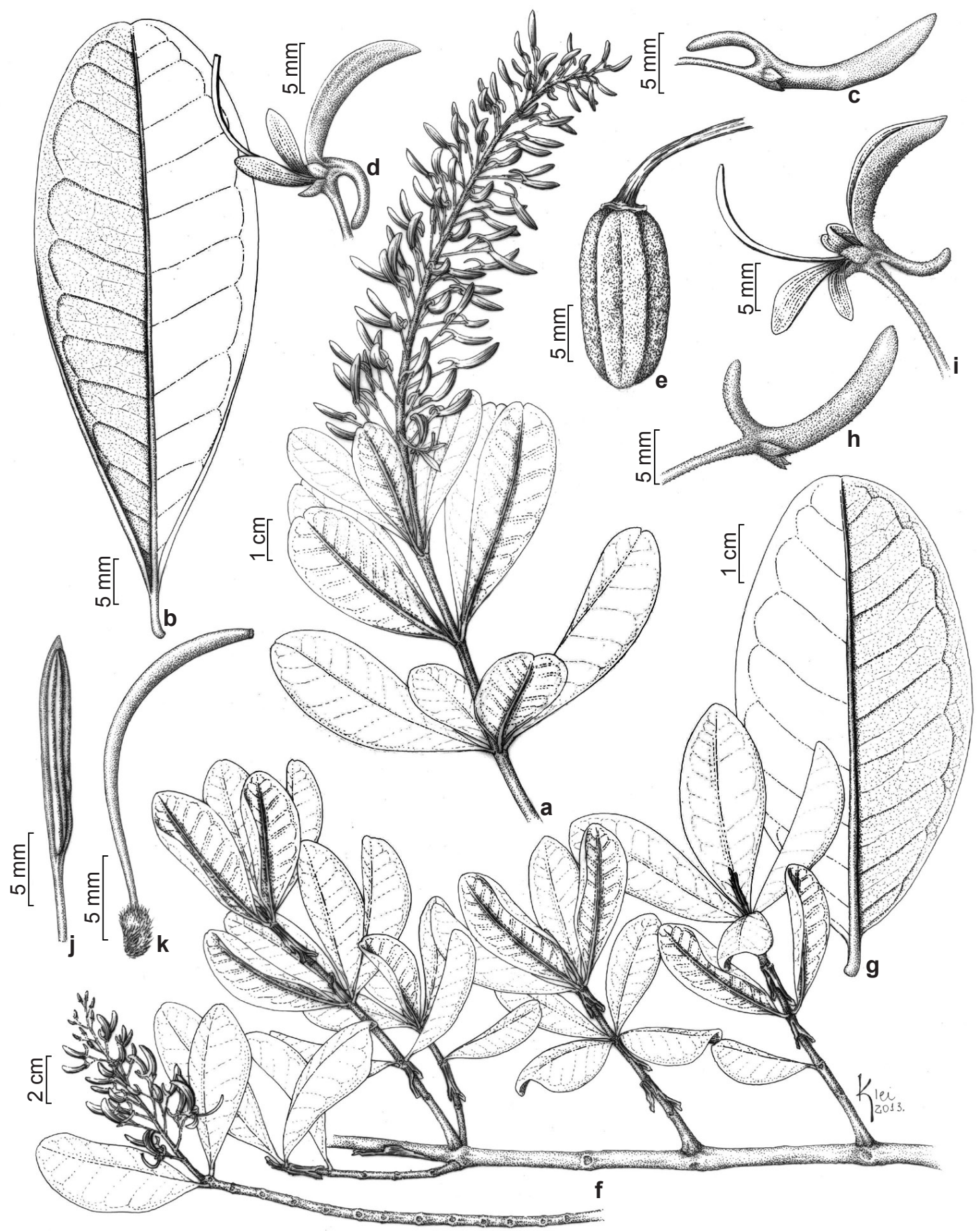

Figura 9 - a-e. Vochysia tucanorum Mart. - a. ramo; b. face abaxial da folha; c. botão floral; d. flor; e. fruto. f-k. Vochysia sp. - f. ramo; g. face abaxial da folha; h. botão floral; i. flor; j. estame; k. gineceu.

Figure 9 - a-e. Vochysia tucanorum Mart. - a. branch; b. abaxial surface of leaf; c. flower bud; d. flower; e. fruit. f-k. Vochysia sp. - f. branch; g. abaxial surface of leaf; h. flower bud; i. flower; j. stamen; k. gynoecium. 
folhas glabras, lâmina foliar espatulada, cartácea, com terço proximal da margem revoluto e pecíolos com 3-6 mm de comprimento. Assemelha-se a $V$. oppugnata (vide comentários desta espécie).

\subsection{Vochysia sp.}

Fig. 9f-k

Arbustos decumbentes e ramificados, 1,5 $\mathrm{m}$ da base ao ápice do fuste. Ramos cilíndricos, casca descamante em placas. Folhas em verticilos 3-4-meros, curto-pecioladas, pecíolo 4-6 mm compr., glabro; lâmina foliar 7,8-9,2 × 3,2-4 $\mathrm{cm}$, coriácea, plana, não glauca, elíptica, ovada ou oblonga, ápice retuso a emarginado, base decurrente, atenuada ou aguda, margem revoluta, face adaxial glabra, nervura primária plana, glabra, nervuras secundárias e terciárias impressas, face abaxial glabra, nervura primária proeminente, nervuras secundárias e terciárias promínulas. Inflorescências ca. $8 \mathrm{~cm}$ compr., tirsos terminais, com cíncinos 1-2-floros, eixos, pedúnculos, pedicelos, brácteas, bractéolas tomentosos; brácteas decíduas. Botões florais 1,3-1,5 × 0,2 $\mathrm{cm}$, retos a incurvos, ápice agudo ou arredondado; sépala calcarada 1,4 cm compr., ápice agudo, tomentosa, sépalas não calcaradas $1,5-2,5 \times$ $1-1,5 \mathrm{~mm}$, ovadas, ápice agudo ou arredondado, tomentosas; cálcar 6-7 mm compr., cilíndrico, reto a fortemente incurvo no botão, chegando a tocar a sépala, incurvo na flor aberta, tomentoso; pétala central $7 \times 3 \mathrm{~mm}$, amarela, espatulada, ápice obtuso a arredondado, base truncada, glabra; pétalas laterais $6 \times 2 \mathrm{~mm}$, amarelas, espatuladas, ápice obtuso a arredondado, base truncada, glabras. Estame 1,3 cm compr., filete $3 \mathrm{~mm}$ compr., antera 1 cm compr., glabra. Ovário $1 \times 1 \mathrm{~mm}$, subgloboso, seríceo; estilete 1,2 cm compr., glabro. Cápsulas não conhecidas.

Material examinado: Diamantina, Mendanha, próximo a rodovia, 28.IV.2012, fl., D.J.P. Gonçalves et al. 492 (UEC); 9.VII.2014, veg., D.J.P. Gonçalves et al. 599 (TEX, UEC).

Ocorre em Minas Gerais, sendo que até o momento apenas um indivíduo foi coletado no entorno do Parque Estadual do Biribiri (PEBI), próximo a Mendanha, município de Diamantina. Coletado com flores no mês de abril, em elevação de $500 \mathrm{~m}$, onde há o predomínio de cerrado s.s. Uma coleta adicional do mesmo indivíduo foi realizada em julho, porém em estado vegetativo. O espécime apresenta ovário piloso e casca dos ramos descamantes, o que o inclui em Vochysia seção Vochysiella subseção Decorticantes. A associação das seguintes características: hábito decumbente, folhas em verticilos 3-4-meros, com margem revoluta e nervuras secundárias e terciárias impressas in vivo tornam a espécie distinta de qualquer outra entidade já descrita da seção. Apesar de ser considerada uma espécie diferente, ainda não foi efetivamente publicada, pois só um indivíduo é conhecido no momento e pretendemos obter mais coletas. Além disso, estudos moleculares em desenvolvimento poderão corroborar o reconhecimento dessa espécie, bem como elucidar as relações entre as espécies da subseção.

\section{Agradecimentos}

Os autores agradecem ao $\mathrm{CNPq}$, a bolsa de Mestrado concedida à primeira autora, à FAPESP, o financiamento do trabalho concedido ao Dr. João Semir, pesquisador responsável (auxílio $\mathrm{n}^{\circ}$ 2011/50654-1) e ao Program de Pós-Graduação em Biologia Vegetal da Unicamp. Agradecemos também ao ilustrador Klei Sousa, ao IEF-MG e às equipes das unidades de conservação (Parque Estadual do Biribiri, Parque Estadual de Serra Negra, Parque Estadual do Rio Preto, Parque Estadual da Serra do Cabral, Estação Ecológica Mata dos Ausentes e Área de Proteção Ambiental Pau de Frutas), ao ICMBio e à equipe do Parque Nacional das Sempre Vivas e aos auxiliares de campo (Matheus M.T. Cota, Larissa Borges, Cristiano Mattioli, José Luiz Gonçalves e Sonival P.M. Gonçalves).

\section{Referências}

Abreu, P.A.A.; Fraga, L.M.S. \& Neves, S.C. 2005. Geologia. In: Silva, A.C.; Pedreira, L.C.V.S.F. \& Abreu, P.A.A. (eds.). Serra do Espinhaço Meridional: paisagens e ambientes. Ed. O Lutador, Belo Horizonte. Pp. 19-43.

Barbosa, A.R. 1999. As espécies do gênero Vochysia Aubl. (Vochysiaceae) ocorrentes no estado de São Paulo. Dissertação de Mestrado. Universidade Estadual de Campinas, Campinas.196p.

BFG. 2015. Growing knowledge: an overview of seed plant diversity in Brazil. Rodriguésia 66: 1085-1113.

Bueno, O.L.; Nilson, A.D. \& Magalhães, R.G. 2000. Callisthene inundata nova espécie de Vochysiaceae e primeiro registro desta família no estado do Rio Grande do Sul, Brasil. Iheringia - Séria Botânica 53: 101-116.

Brummitt, R.K. \& Powell, C.E. 1992. Authors of plant names. Whitstable Litho, Whitstable. 736p.

Echternacht, L.; Trovó, M.; Oliveira, C.T. \& Pirani, J.R. 2011. Areas of endemism in the Espinhaço Range in Minas Gerais, Brazil. Flora 206: 782-791. 
França, F. 1996. O gênero Callisthene Mart. \& Zucc. (Vochysiaceae) no estado da Bahia. Sitientibus 15: 41-47.

França, F. 2009. Vochysiaceae. In: Giulietti, A.M.; Rapini, A.; Andrade, M.J.G.; Queiroz, L.P. \& Silva, J.M.C. (orgs.). Plantas raras do Brasil. Conservação Internacional, Universidade Estadual de Feira de Santana, Feira de Santana. Pp. 408-410.

Giulietti, A.M.; Pirani, J.R. \& Harley, R.M. 1997. Espinhaço range region. In: Davis, S.D.; Heywood, V.H.; Herrera-Macbride, O.; Villa-Lobos, J. \& Hamilton, A.C. (eds.). Centres of plant diversity. A guide and strategy for their conservation. The Americas. Vol. 3. WWF/IUCN, Cambridge. Pp. 397-404.

Gonçalves, D.J.P.; Yamamoto, K. \& Romero, R. 2013. Vochysiaceae no Parque Nacional da Serra da Canastra, Minas Gerais, Brasil. Rodriguésia 64: 863-875.

Joly, A.B. 1970. Conheça a vegetação brasileira. EDUSP, Polígono, São Paulo. 181p.

Kawasaki, M.L. 1995. Vochysiaceae. In: Stannard, B. (ed.). Flora of Pico das Almas, Chapada Diamantina, Bahia, Brazil. Royal Botanic Gardens, Kew. Pp. 639-643.

Kawasaki, M.L. 2006. Vochysiaceae. In: Kubitzki, K. (ed.). The families and genera of vascular plants. Vol. 9. Springer, Berlin. Pp. 480-487.

Köppen, W. 1931. Climatología. Fondo de Cultura Económica, Buenos Aires. 390p.

Litt, A. 1996. Phylogeny of the Vochysiaceae: implications of molecular data for floral evolution. American Journal of Botany 83(abstracts): 175.

Litt, A. 1999. Floral morphology and phylogeny of Vochysiaceae. PhD Dissertation. City University of New York, New York. 264p.

Marcano-Berti, L. 1969. Un nuevo género de las Vochysiaceae. Pittieria 2: 3-27.

Martins, H.F. 1981. O gênero Callisthene Martius (Vochysiaceae). Ensaio para uma revisão taxinômica. Dissertação de Mestrado. Universidade Federal do Rio de Janeiro, Rio de Janeiro. 115p.

Martins, H.F. 1988. Species novae in Brasilia Vochysiacearum. Bradea 5: 149-151.

Neves, S.C.; Abreu, P.A.A. \& Fraga, L.M.S. 2005. Fisiografia. In: Silva, A.C.; Pedreira, L.C.V.S.F. \& Abreu, P.A.A. (eds.). Serra do Espinhaço Meridional: paisagens e ambientes. Ed. O Lutador, Belo Horizonte. Pp. 47-58.

Passos, V.M. \& França, F. 2003. Vochysiaceae da Chapada Diamantina, Bahia, Brasil. Sitientibus série Ciências Biológicas 3: 35-43.

Pohl, J.B.E. 1828 ou 1829. Vochysiaceae. In: Pohl, J.B.E. Plantarum Brasiliae icones et descriptiones hactenus ineditae. Vol. 2. Antonii Strauss, Wien. Pp. 15-31.

Radford, A.E.; Dickison, W.C.; Massey, J.R. \& Bell, C.R. 1974. Vascular plant systematics. Harper and Row, New York. 891p.
Rapini, A., Mello-Silva, R. \& Kawasaki, M.L. 2002. Richness and endemism in Asclepiadoideae (Apocynaceae) from the Espinhaço Range of Minas Gerais, Brazil - a conservationist view. Biodiversity and Conservation 11: 1722-1746.

Sajo, M.G. \& Rudall, P.J. 2002. Leaf and stem anatomy of Vochysiaceae in relation to subfamilial and suprafamilial systematics. Botanical Journal of the Linnean Society 138: 339-364.

Saadi, A. 1995. A geomorfologia da Serra do Espinhaço em Minas Gerais e de suas Margens. Geonomos 3: 41-63.

Sarmiento, G. 1983. The savannas of tropical America. In: Bouliere, F. (ed.). Ecosystems of the world: tropical savannas. Elsevier, Amsterdam. Pp. 245-288.

Semir, J. 1991. Revisão Taxonômica de Lychnophora Mart. (Vernonieae: Compositae). Tese de Doutorado. Universidade Estadual de Campinas, Campinas. $515 \mathrm{p}$.

Senterre, B. \& Obiang, D. 2005. Nouvelles découvertes à propos des Vochysiaceae africaines: Erismadelphus Mildbr. et Korupodendron Litt \& Cheek. Taxonomania 17: 3-18.

Shimizu, G.; Gonçalves, D.; Amaro, R.; Kutschenko, D. \& Novaes, L. 2014. Vochysiaceae. In: Martinelli, G.; Messina, T. \& Santos Filho, L. Livro vermelho da flora do Brasil - Plantas raras do Cerrado. Andrea Jakobsson Estúdio, Rio de Janeiro. Pp. 274-277.

Shimizu, G.H. \& Yamamoto, K. 2012a. Flora da Serra do Cipó, Minas Gerais: Vochysiaceae. Boletim de Botânica da Universidade de São Paulo 30: 63-87.

Shimizu, G.H. \& Yamamoto, K. 2012b. Vochysiaceae. In: Jacobi, C.M. \& Carmo, F.F. Diversidade florística nas Cangas do Quadrilátero Ferrífero. Código Editora, Belo Horizonte. Pp. 209-210.

Souza, V.C. \& Lorenzi, H. 2012. Botânica Sistemática. $3^{\text {a }}$ ed. Instituto Plantarum, Nova Odessa. 768p.

Stafleu, F.A. 1948. A monograph of Vochysiaceae. I. Salvertia and Vochysia. Recueil des Travaux Botaniques Néerlandais 41: 397-540.

Stafleu, F.A. 1952. A monograph of Vochysiaceae. II. Callisthene. Acta Botanica Neerlandica 1: 222-242.

Stafleu, F.A. 1953. A monograph of Vochysiaceae. III. Qualea. Acta Botanica Neerlandica 2: 144-217.

Stearn, W.T. 2004. Botanical Latin. $4^{\mathrm{a}}$ ed. Timber Press, Portland. 560p.

Thiers, B. [continuamente atualizado]. Index herbariorum: a global directory of public herbaria and associated staff. New York Botanical Garden's Virtual Herbarium. Disponível em $<$ http://sweetgum.nybg. org/science/ih/>. Acesso em 7 janeiro 2016.

Vianna, M.C. 1980. O gênero Vochysia Aubl. (Vochysiaceae) no estado do Rio de Janeiro. Rodriguésia 55: 237-323.

Vianna, M.C. 2002. Vochysia Aubl. (Vochysiaceae) na Mata Atlântica: morfologia e taxonomia. Tese de Doutorado. Universidade Federal do Rio de Janeiro, Rio de Janeiro. 289p. 
Warming, E. 1875. Vochysiaceae. In: Martius, C.F.P. von; Eichler, A.W. Flora brasiliensis. Frid. Fleischer, Leipzig. Vol. 13, pp. 17-116.
Yamamoto, K. 2009. Flora de Grão-Mogol, Minas Gerais: Vochysiaceae. Boletim de Botânica da Universidade de São Paulo 27: 131-136.

\section{Lista de exsicatas}

Almeda, F. 8950 (4.3). Anderson, W.R. 8817 (1.2), 8853 (2.2), 35389 (4.3), 8590 (4.4), 35562 (4.12). Araújo, A.O. 329 (4.3). Barbosa, A.R. 290 (4.3). Mello Barreto, H.L. 9677 (1.1), 9750 (2.5), 9484, 9568 (4.3). Braga, M.M.N. s.n. (BHCB 47139, ESA 65994, SP 340266, SPF 140598) (2.1). Cid Ferreira, C.A. 6043 (2.5). Cordeiro, I. CFSC 6777 (1.1). Costa, F.N. 590 (2.1), 928 (2.5), 846 (4.4). Costa, L.V. 477 (2.5), 474 (4.4), 473 (4.12). Cota, M.M.T. 344 (4.9). Duarte, A.P. 8544 (4.1). Franco, G. 2923 (4.7). Foresto, E.B. 56, 105 (4.1), 46 (4.12). Giulietti, A.M. s.n. (SPF 21054, UEC 152906), CFCR 2470 (2.1), CFCR 2536 (4.1), CFCR 2215 (4.3). Gonçalves, D.J.P. 202, 203, 226, 326, 438, 439, 479, 483, 539 (1.1), 186, 187, 249, 250, 464 (1.2), 199, 200, 210, 218, 546 (1.3), 102, 103, 112, 147, 149, 153, 159, 160, 169, 175, 208, 220, 221, 236, 242, 257, 281, 283, 307, 319, 349, 380, 410, 512, 532, 540, 541 (2.1), 92, 100, 151, 156, 161, 172, 235, 238, 251, 255, 285, 292, 382, 407, 408, 437 (2.3), 93, 101, 164, 165, 173, 188, 229, $254,256,284,286,293,383,407,409,419,420,436,503(2.4), 104,154,155,157,166,171,174,183,189,237,253,259,294,322$, $450,454,455,508,533,542(2.5), 291,547(3.1), 181,190,213,214,215,244,279,335,336,337,545(4.1), 232(4.2), 98,99,107$, $113,141,142,144,145,148,150,152,158,170,185,204,222,243,266,273,282,289,290,298,302,304,308,309,310,311,312$, $313,314,316,320,324,325,326,333,334,342,348,351,352,354,374,480,515,530(4.3), 105,106,488,489,490,505,511,528$, $529,531,543,544(4.4), 108,231,372,421,428,429,430,431,474,475,476,477,478,484,509,516,523,524,534,535,537(4.5)$, 494 (4.6), 487 (4.7), 491, 497 (4.10), 146, 163, 230, 245, 261, 265, 267, 280, 287, 288, 296, 297, 299, 303, 306, 315, 317, 318, 353, $356,360,378,379,521$ (4.11), 143, 167, 168, 228, 246, 248, 271, 272, 278, 301, 305, 323, 332, 373, 413, 416, 417, 418, 536 (4.12), 492, 599 (4.13). Grandi, T.S.M. 8120 (4.3). Harley, R.M. CFCR6155 (2.1), 17866 (4.7). Hatschbach, G. 49720, 51100, 73781 (1.2), 49820, 69666 (2.1), 27434, 31642, 51115 (2.2), 51904 (2.5), 27028 (4.1), 50278 (4.3), 51119, 51200 (4.4), 36501, 51222 (4.9), 51057 (4.12). Hensold, N. CFCR 2655 (4.3). Irwin, H.S. 27557 (1.1), 27496 (2.1), 22292 (2.3), 22637 (4.1), 22695 (4.3), 20914 (4.5), 28375 (4.9), s.n. (UEC 23998) (4.10), 21847 (4.11), 28441 (4.12). Isejima, E. CFCR 5533 (2.1). Joly, A.B. CFSC 2966 (4.9). Leitão Filho, H.F. 17343, 27377 (1.2), 27663 (2.4), 27454, 27795, 27670, 27780 (2.5). Lemos Filho, J.P. s.n. (BHCB 41138, SP 330120) (2.3), s.n. (BHCB 41139, SP 330119) (2.4). Lombardi, J.A. 3853 (1.1), 3440 (1.2), 3366 (1.3), 3394, 3480 (2.1), 3490 (4.1), 4168 (4.3). Lopes, A.V. 26 (4.2). Maguire, B. 44687 (2.1), 44771 (4.12). Magalhães, M. 18884 (4.5). Martinelli, G. 6314 (4.8). Martins, F.R. 17139 (1.2). Mello-Silva, R. 1047 (1.2), 1053 (2.4), 1039, 1045 (4.5), s.n. (UEC 53845) (4.12). Mello, F.N.A. 38, 472 (2.1), 135, (2.5). Mello Barreto, H.L. 8324 (1.1). Menezes, N.L. CFCR 9540 (4.11). Mexia, Y. 5878 (4.4), 5767 (4.12). Nakajima, J.N. 4665, 4671, 4968 (2.1). Occhioni, P. 5627 (4.12). Pedralli, G. s.n. (BHCB 14005, UEC 63182) (4.12). Pereira, E. 1503 (4.1). Pirani, J.R. CFSC 12902 (1.1), CFCR 7881 (4.3), s.n. (UEC 152910) (4.5), 3976 (4.12). Rodrigues, R.S. 1565 (4.4). Romero, R. 8114 (2.1), 8188 (4.3). Rosa, P.O. 946, 1150 (2.1), 1150 (2.4), 923 (2.5), 960 (4.1). Salatino, A. 36, 41, 85 (2.1). Salino, A. 4762 (2.1). Semir, J. s.n. (UEC 52323) (1.1), 17509 (4.4). Shepherd, G.J. 3974 (4.3). Souza, V.C. 29639 (1.1), 29633 (2.1), 11844, 11894 (4.3), 11886, 20918 (4.4), 8265 (4.5), 25396 (4.11). Versiane, A.F.A. 260 (1.2). Williams, L.O. 6905 (4.5). 